Portland State University

PDXScholar

\title{
An investigation of the combined effect of agency support and professional social workers' training on the type of family therapy practiced by agency-based social workers
}

\author{
Betsy Marsh McCartor \\ Portland State University \\ Margaret Labby \\ Portland State University
}

Follow this and additional works at: https://pdxscholar.library.pdx.edu/open_access_etds

Part of the Family, Life Course, and Society Commons, and the Social Work Commons Let us know how access to this document benefits you.

\section{Recommended Citation}

McCartor, Betsy Marsh and Labby, Margaret, "An investigation of the combined effect of agency support and professional social workers' training on the type of family therapy practiced by agency-based social workers" (1977). Dissertations and Theses. Paper 1926.

https://doi.org/10.15760/etd.1925

This Thesis is brought to you for free and open access. It has been accepted for inclusion in Dissertations and Theses by an authorized administrator of PDXScholar. Please contact us if we can make this document more accessible: pdxscholar@pdx.edu. 
AN INVESTIGATION OF THE COMBINED EFFECT OF AGENCY SUPPORT AND PROFESSIONAL SOCIAL WORKERS' TRAINING ON THE TYPE OF FAMILY

THERAPY PRACTICED BY AGENCY-BASED SOCIAL WORKERS

by

Betsy Marsh McCartor

Margarèt Labby

A practicum submitted in partial fulfillment of the requirements for the degree of

MASTER OF SOCIAL WORK

Portland State University

1977 


\section{ACKNOWLEDGEMENTS}

We wish to express gratitude to our families for their support and encouragement in this practicum. To Dan Labby, and Megan, Scott and John McCartor, go our warmest thanks. Nancy Koroloff gave much time and help on our evaluation section, and Marian Ayerza encouraged our thinking and scholarship throughout many consultations with her. We wish lastly to thank the social workers in our selected agencies who facilitated our task by their interest and cooperation. 


\section{PREFACE}

During our first year as social work students, we discovered that each of us had independently been attracted to family therapy as an outgrowth of our personal life experience. We had each known family stress while becoming career women and raising three children. Both of us began our professional lives as teachers and were well acquainted with the impact of family life on students and the importance of healthy family functioning. Further, we had both participated in workshops and were familiar with the literature and practice of family therapy as part of our social work training. We felt, therefore, uniquely prepared to study family therapy for our research practicum. It seemed a natural choice.

Betsy Marsh McCartor Margaret Labby 
ACKNOWLEDGEMENTS...........................

PREFACE............................... iv

LIST OF FIGURES......................... v

CHAPTER

I INTRODUCTION........................ 1

II A. AN OVERVIEW OF THE DEVELOPMENT OF FAMILY THERAPY

B. AN HISTORICAL REVIEW OF SOCIAL WORKERS' ATTITUDES TOWARDS WORKING WITH THE FAMILY..... 24

II METHODOLOGY........................ 34

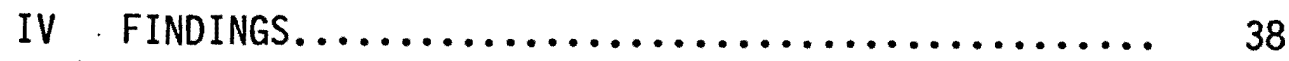

$\checkmark$ CONCLUSIONS AND INTERPRETATIONS............. 51

FOOTNOTES

Chapter I............................. 60

Chapter II A............................. 60

Chapter II B......................... 62

Chapter III......................... 64

Chapter $v_{. \ldots \ldots \ldots \ldots \ldots \ldots \ldots \ldots \ldots \ldots \ldots \ldots \ldots \ldots} 64$

BIBLIOGRAPHY.............................. 65

APPENDIX A................................. 70

APPENDIX B................................ 73

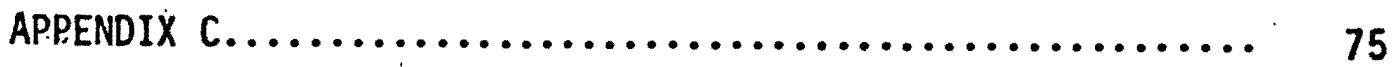


I SAMPLE SIZE AND CHARACTERISTICS (1976)...... 40

II RELATIONSHIP OF AGENCY SUPPORT TO PRACTICE OF FAMILY THERAPY.

II I PROPORTION OF SOCIAL WORKERS WHO LABEL SELVES FAMILY THERAPISTS AND PROPORTION WHO PRACTICE ACCORDING TO FSAA DEFINITION.............. 45

IV RELATIONSHIP BETWEEN YEAR OF GRADUATION AND FAMILY THERAPY PRACTICE $1976 \ldots \ldots \ldots \ldots \ldots \ldots$

$\checkmark$ CHARACTERISTICS OF SOCIAL WORKERS PRACTICING FAMILY THERAPY. 


\section{INTRODUCTION}

A11 persons are born into some form of family unit. The traditional family is a unit of people who live together over periods of time and have ties of marriage and kinship. Even if that unit is separated, as in death or adoption, qualities of one's personhood are closely connected with forebears and parents. Whether for good or bad, the family profoundly affects the individual. As Michael Novak says:
Yet, clearly, the family is the seedbed of economic skills, money habits, attitudes toward work, and the arts of fin- ancial independence. The family is a stronger agency of educational success than the school. The family is a stronger teacher of religious imagination than the church. Political and social planning in a wise social order begin with the axiom 'What strengthens the family strengthens society.' Highly paid, mobile, and restless professionals may disdain the family (having been nurtured by its strength) but those whom other agencies desert have only one insti- tution in which to find essential nourishment. ... If things go well with the family, life is worth living; when the family falters, life falls apart. 1

In the last 30 years social patterns have increased the pressures on the family unit from outside as well as inside. As society becomes more technical and jobs more specialized, the wage earner is enticed to move to where the better jobs are. The more mobile American family moves away from relatives and the network of familiar people and environments. Skills at adapting quickly are needed and many families are $i 11$ prepared. The isolation of the family may, in part, be seen as a by product of a competitive work system which is based on status and power variables rather than the personal qualities of those involved. 
As urban replaces rural life, values within the society shift. The city pace accelerates movement of the family. Efficiency and speed are more valued than caretaking and craftsmanship. Apartment living, public transportation and the media increase a superficial contact with people and decrease sustained contact. It seems that the schools and churches, traditionally supportive of family life, are less influential now than they were in the past.

Another pressure is blurred family roles. In previous days, children in the family were a productive part of its economic fortune. At present, children seem to be an economic liability for the family. With more women in the labor force, the family unit is less often together for consistent and nourishing contact with each other. There is little societal reinforcement for staying with a role and doing it well.

In addition, divorce is more acceptable now than in the past. A new theme echoes through periodicals and books: divorce may be a sign of growth and self-fulfillment; lengthy marriage may equal stagnation. However, with more divorces being granted, both children and parents are faced with multiple and rapid necessary adjustments.

The women's movement and increased contraceptive options provide the American woman with a new freedom. She has increased control of her body and more options for choice in her life plans. Unlike women in previous generations, she may choose when and if she chooses to be a parent and when and if she wants to take a job. If she chooses to do both concurrently, she may feel guilty about the quality of her parenting. 
The family is an important unit. Many stresses impinge upon it. The church and extended family are less influential on the family today. The school is less influential. Where does the family turn for support? Social agencies have become the source for low cost aid for the family. The following study explores the extent to which social agencies provide this support for families in this community. 


\section{CHAPTER II}

\section{A. AN OVERVIEW OF THE DEVELOPMENT OF FAMILY THERAPY}

Tracing the development of family therapy presents formidable obstacles. One of the major obstacles is that "the family is a meeting ground for many sciences, an area where the boundaries of many fields of knowledge overlap." 1 Studies of family organization draw. upon the behavioral sciences--psychology, sociology, anthropology, social psychology--as well as the biological sciences. Studies of family function draw on the above as well as wide-ranging theories--general systems, communications, and cybernetics, for example. Another obstacle is that therapists from a wide variety of professional disciplines have experimented with family therapy--psychiatrists, psychoanalysts, general practitioners, pediatricians, psychologists, social workers, counselors, nurses and clergymen, among others.

A further obstacle is one of defining what precisely is meant by the term family therapy. Historically, analytic psychology maintained an interest in the family but treatment was primarily oriented to the individual family member. For a number of years in the fifties and sixties, many child psychiatrists in clinics believed they practiced family therapy. As one therapist noted:

We tended to call it much more correctly family-oriented therapy. I would now say that at that time we did not practice family therapy, the difference being of orientation and aim. We had become aware that families, specifically parents, interfered with the treatment of individuals, and that often family members other than the designated patient 
needed help too. We made a diagnosis and sometimes therapeutic contact with the patients and occasionally with the other siblings, but the aim was to improve our ability to help an individual, either the individual designated as patient by the family or by us. 2

Another writer agrees, saying:

The terms family counseling, family therapy and family treatment have been used relatively interchangeably in the li.terature to describe a wide variety of clinical approaches to the family. Even many clinicians who have limited their practice to individual treatment consider themselves 'famijyoriented' in that they interview several family members in the course of diagnosing and formulating treatment goals for their patients... (It is) important to distinguish 'familyoriented' treatment from those family treatment approaches which focus on the family as a unit and which usually involve three or more family members meeting together (conjointly) with the same therapist. 3

Sanford Sherman says the same:

If we are to understand the individual, we must also understand the structure, function and vital processes of the group as a discrete system. It is for this reason that, in this past decade family diagnosis came to the fore as a focus of interest replacing an interest in 'family-oriented' diagnosis. 'Changing from family-oriented to family diagnosis and treatment is more than an increase in the intensity of the same approach. It represents a shift to viewing the distress of the individual as less the problem than a symptom of the problem of pathology in the whole family.' Family diagnosis is oriented to the 'client in the family' and their reciprocal interplay; it replaces the separation expressed in the phrase 'the client and the family.' The 'in' orientation is holistic; the 'and' orientation is atomistic. These differing orientations reflect differences not only in personality theory but also in practical family analysis. One approach is to comprehend and analyze the whole (the family) as a necessary concurrent condition to understanding or analyzing the part (the individual); the other approach defines components (individuals) and attempts to comprehend the whole (the family) by interrelation and synthesis. 4

The difficulty is more, however, than differentiating between family-oriented therapy and therapy focusing on the family as a unit.

The term family itself has expanded to include the extended family 
and the family "network" as well as the nuclear family. As Jay Haley writes:

By the beginning of the 1960 's, many family therapists were widening their focus to include not only the nuclear family but also the extended kin in family treatment. Later in the 1960's the unit of treatment broadened still more. The 'family' language began to be applied to all systems with a history and a future, so that at times the unit of treatment was a larger ecological one yielding network descriptions and network therapy. Some family therapists realized that they had been talking about a family in isolation such as they had once talked about the isolated individual. 5

These obstacles--the many different disciplines and sciences contributing to the development of family therapy and the difficulty in defining precisely what the term means--are formidable. Nevertheless, a general trend is observable. Since the beginning of this century, the emphasis of human behavior studies has shifted from one solely on the individual to one that includes his relationships and more recently to the broad inclusion of the individual in his support system: his family and society.

What follows is a brief historical review of some of the major trends that have brought about this shift and paved the way for the development of the "new treatment modality" broadly labeled family therapy. 6 Four separate trends will be described: a) a focus on the intrapsychic dynamics of the individuat; b) a focus on the individual and the relationship; c) a focus on the individual in the relationship; d) a focus on the family as a system. 


\section{a) FOCUS ON THE INTRAPSYCHIC DYNAMICS OF THE INDIVIDUAL}

Impact of Freudian Theory on the Study and Treatment of the Family

During the first four decades of the twentieth century, psychotherapy directed its attention upon individuals and their intrapsychic systems and away from the family. Freudian theory recognizes that the family significantly influences the development of the child and that an understanding of the family is significant to the treatment of the patient. It assumes:

that the patient's family, or particular members of it, was intimately associated with the pathological reaction of the patient... Such family-related concepts as psychic trauma, the role of family members in interfering with psychosexual trauma, the process of identification, superego development, and the Oedipus Complex are central to his theories. Some have even looked upon Freud's treatment of Little Hans by the technique of supervising Hans' father, as evidence of his acceptance of family therapy.7

Powerful influences derived from other psychoanalytic concepts regarding the mechanisms of therapy have kept the family out of treatment. Freud was a physician trained in the medical model designed for diagnosing and treating disease located within the patient. Although human behavior is not strictly analogous to the biological, using the medical model directed the focus of treatment toward the individual and away from direct observation of the family. ${ }^{8}$ The analyst is primarily concerned with the patient's subjective interpretation of experience rather than with real events: how the person sees the situation, what his expectations are and how he responds. The therapist plays a passive, reflective and interpretive role; treatment requires the elicitation and 
analysis of the transference neurosis in order to relieve the traumatic early experiences that are repressed in the unconscious and responsible for the pathology. Attention is paid within treatment to the transference as it recreates early experience; any direct contact with the family would interfere with the transference. Traditionally both psychiatrists and psychoanalysts spend large amounts of time listening to a patient's account of his family yet at the same time avoid the opportunity of firsthand observations of the family.

b) FOCUS ON THE INDIVIDUAL AND THE RELATIONSHIP

Forces Modifying Freudian Theory

Gradually there was a shift away from the traditionally exclusive emphasis on intrapsychic conflict rooted in the unconscious. ${ }^{9}$ An awareness developed that the individual's intrapsychic life was not entirely an internal process but a result of the interaction with the environment. Relationships between people began to be examined. The individual was seen to have significance on the lives of others, especially members of the family, and to have the potential for modifying the existing environment and creating new ones as well. The concept of adaptation helped focus on the "why" of illness rather than on the fixed psychopathological systems; that is, on the pathology of relationships as well as on the pathology of individuals. ${ }^{10}$ Ego Psychology led by Hartmann and others began focusing on patterns of coping, defense, ego integration and social interaction. 11

Somewhat later the so-called "neo-Freudians" emphasized an awareness of the relationship between the individual and his social environment. ${ }^{12}$ 
Erich Fromm pointed out man's dilemma in trying to balance his need for autonomy and independence with his need for social acceptance and his fear of being alone. Karen Horney indicated the importance of the here-and-now and of the patient's real-life situation in treatment. Sullivan emphasized the importance to an individual's development of learning how to consider and respect the needs of another as much as one's own. Although these forces modified Freudian theory, the focus remained primarily on the individual.

At the beginning of World War II, social psychology, psychology, anthropology and sociology were contributing knowledge about the family unit. Social psychology studied the elements of role, of class, of family structure and of small groups. Anthropological studies of different forms of parenting in other cultures led to the recognition of social factors which impinged upon the family. "Psychodynamic science (was) making room for social science, and social science (was): making room for psychodynamic theory." 13 Impact of Studies of Large and Small Groups

Freudian concepts had been developed in association with the treatment of educated, well-motivated, middle-class patients suffering from neurotic disorders. Treatment was expensive, time-consuming and not designed to deal with masses of people or the severely emotionally disturbed. World War II forced analysts and psychiatrists to move out of their private practice into the armed services where large numbers of soldiers from a wide variety of backgrounds suffering from severe emotional disturbances required treatment. One-to-one therapy not only proved inefficient; it was ineffective. 
New methods of treatment were needed. A natural way to deal with masses of people was to treat groups of patients with similar problems through discussion. Clinicians had to move from thinking about treating one individual to treating groups of individuals. A new orientation was required. Studies of group interaction took two separate approaches. One focused on how individuals behave in a group; another on how the group behaved as an entity. Both studies did much to remove the blocks in the way of permitting therapists to see members of a patient's family.

The interest in group psychotherapy that emerged after World War II represented a major change in the theory and technique of understanding human behavior. Studies of how the individual behaved in a group revealed that intrapsychic emotional and behavioral problems could be made manifest in interpersonal behavior and could be treated at that leve1. As Parloff notes:

Just as in individual therapy the patient's reaction to the therapist could be interpreted as evidence of the relationship between the patient and a parent figure, so in group therapy the patient's reactions to other members of the group could be interpreted as revealing his relationships to members of his family. Moreno facilitated this process in psychodrama which involved the therapist and group members' self-consciously attempting to take roles representing important figures in the patient's family. The assumption that the therapy group was experienced by patients as a transference family group was and is widely held. Where previously the therapist was limited to analyzing the relationship between himself and the patient as a prototype for the parental situation, the group therapist now found himself in a position of being able to see, in addition, the patient's relationships with other persons who stood in the position of siblings, parents and other significant figures. From here it was a short step to wondering about the advantages of observing the patient interact with his actual rather than his transference family. 74 
In group psychotherapy, however, the focus remained on therapy for the individual rather than for the group. Studies of group dynamics provided information about how groups function as a single entity; helping groups learn how to function more effectively became one of the goals. It would take a relatively simple step to move from practicing psychotherapy with "artificially composed" groups of people to"naturally composed" groups such as families. 15

Changes in theories about the nature of the client-therapist relationship were slow but steady. An exclusive reliance on the oneto-one mode was no longer the only mode. Two or more clients and one or more therapists were now involved in the therapy process. Fears that the transference would be diluted were diminished. Therapists became more active; more open and more spontaneous in the process. ${ }^{16}$

Impact of Child Psychiatry and the Child Guidance Movement

A basic concept of psychoanalysis was that the child was the "victim of the parent's' conscious or unconscious malevolence." 17 With the development of child analysis and child psychiatry, child therapists began to feel:

on the basis of mounting clinical evidence... that parents were worth studying if only because they were so wrong and so bumblingly diabolical. The patient's mother appeared to have the remarkable knack of being able singlehandediy to produce neuroses, psychosomatic syndromes, psychoses and even juvenile delinquency with equal facility. . 18

The mother was seen as the victimizer; the child as the victim. Therapists recognized that their work with the child was frequently thwarted by parental interference when the child returned home. 
To counteract this problem, the mother was asked to enter treatment although she would be seen by a different therapist than the one treating her child in order to prevent the transference from being contaminated. To understand the nature of the relationship between family members, the two therapists would meet to share information.

The child guidance movement in America, developed through the efforts of juvenile courts to treat masses of delinquent children as economically and expeditiously as possible,19 added a third specialist. Psychological testing became part of the investigation of the family. Teams would be composed of the psychiatrist working on the intrapsychic level with the child, the sociai worker treating the mother to supplement the work of the psychiatrist, and the psychologist responsible for the testing and diagnostic studies. (In a lecture at Good Samaritan Hospital in June 1976, Dr. Allen Enlow remarked that this constituted the Holy Trinity Approach: the psychiatrist was the Father, the psychologist the Son, and the social worker the Holy Ghost or Spirit.) At these team meetings therapists would:

discuss their patients not simply as individuals of a specifiable dynamics but as individuals involved in a reciprocal dynamic relationship with each other. The goal of therapy gradually shifted from that of making the patient independent of his family, to clarifying the relationship between parent and patient in order that a better relationship could develop and the child could be a member of the family once again, or perhaps for the first time... one of the factors which may have given impetus to the decision to place therapy of family members in the hands of one therapist rather than depending upon conferences between their therapists was 
that the therapist would rather take the risk of countertransference and transference problems than the risk of dealing with one of his colleagues. Social workers, marriage counselors, and even some particularly adventurous psychoanalysts... reported having treated marital partners and siblings and having survived the transference and countertransference ordeals. These successful experiments may have stimulated other therapists to try their luck at treating more than one member of the family. 20

In fact, Nathan W. Ackerman, a child psychiatrist, was one of the first to experiment with treating whole families.

Impact of Studies of Special Groups of Emotionally Disturbed

A number of clinicians developed skills as family therapists through their studies of schizophrenics and other groups of severely disabled. These therapists noted, as did child therapists, that once patients returned home, they frequently regressed. Clinicians became interested in studying the patients' real rather than fantasied and subjective experiences with their families. Families were invited to visit patients in the hospital where group meetings of the family, the patient and the therapist were held. 21 Murray Bowen actually invited families of his schizophrenic patients to move into the hospital to help with treatment. 22 The first studies postulated that the psychosis was the product of the mother-child relationship; Freida FrommReichman coined the term "schizophrenogenic mother."23 As the relationships between the mother and the patient, and later both parents and the patient were studied, therapists began focusing their treatment on changing the sequence of behavior between members of the family. rather than on changing the patient. Frequently it became apparent 
that the schizophrenic--the identified patient--was not the sickest member of the family; the family itself was dysfunctional. The move to treating the entire family as a unit was a natural development.

Impact of Marriage Counseling

Disagreement exists as to whether marital and family therapy are two separate modalities or one and the same. There is, of course, the Journal of Marriage and Family Counseling published by the American Association of Marriage and Family Counselors. Marriage counseling clinics serving couples opened in the thirties while family clinics are of later origin. Marriage counseling has made two contributions. One has been its focus on the marital relationship, the other the "technique of conjoint marital therapy."24

\section{Impact of Social Learning Theory}

Social learning theory based on behavioral psychology offers another approach to changing behavior, providing a systematic set of operations for bringing about change. 25 At first this approach focused on the individual; that is, the therapist reinforcing the child for correct behavior. From training the child, therapists moved to training one or both parents to reinforce the child for correct behavior. Now entire families are being trained. Instead of focusing on one person being reinforced, therapists focus on the total family by "emphasizing the need for clear family rules and attendant rewards and punishments." 26 
c) FOCUS ON THE INDIVIDUAL IN THE RELATIONSHIP

\section{Impact of General Systems Theory}

General systems theory is more a "point of view" than a science, "a way of looking at phenomena in their total relationships rather than in isolation from one another."27 According to systems theory science has tended to look at phenomena in the past as a "closed" system, in isolation, similar to the way analytic psychology studied the individual as separate from his environment. With the information explosion, however, it becomes more difficult to "consider events apart from the context in which they appear, without distorting the truth and reaching misleading conclusions."28 General systems theory:

is an expression of this more connected, encompassing attitude which attempts to formulate basic principles which must apply to al1 systems, no matter what the size or level. Atoms, molecules, cells, tissues, individuals, groups, societies, and so on, are all seen in terms of a hierarchy of open systems, like a succession of Chinese boxes one within another, in which the lesser systems have some independence from, yet are also influenced by and a part of large systems. 29

The systems theory "penetrated a variety of fields in the social sciences, bringing increasing concern with the context of a person and his relationships with others." 30 Carried to its logical extension, the family can be seen as only one of many social groups which affect human behavior preparing the way for family therapy including in its orientation family networks, sma11 and even large communities or social groups.

Impact of Cormunity Mental Heal th Movement

In the early sixties, mental health had become such a problem of national concern that, for the first time in history, a President, 
John F. Kennedy, transmitted a special message to the U. S. Congress on the subject. He recommended a bold new approach. Instead of caring for the mentally $i 11$ in custodial institutions far removed from patients' homes, the administration offered a program which would establish a "network of adequately staffed community facilities providing a series of preventive, diagnostic, therapeutic and restorative services" close to the patients' homes. ${ }^{31}$ Reintegrating recovered mental patients into the community was not the only goal, however. In his message, President Kennedy stated that almost every American family would, at some time, experience a case of mental illness. His new program establishing Comprehensive Community Mental Health Centers was intended to "promote positive mental health" as well as prevent mental illness. 32

Little controversy surfaced over the need for such a program. Mental health professionals--"perhaps for the sake of clarity" one writer noted--had developed tools for treating intrapsychic problems of individuals but only for a relatively, small group: educated, well-motivated, middle-class patients suffering from neurotic disorders. ${ }^{33}$ The severely mentally $i 11$ were shockingly neglected; a disproportionate number came from among the poor and underprivileged. Furthermore, a huge "superstructure of fragmented services and programs, often at a distance both psychologically and geographically from the people who needed them" had been erected to serve the social and emotional welfare of the masses of poor. 34 Many professionals saw these and other social institutions as the cause of emotional and social problems. 
For years the field of mental health had been split into two camps. One group saw social and emotional problems stemming from the weakness and inadequacy of the individual. Traditional tools of personality dynamics could be used to help him. The other saw problems as stemming from the weakness and inadequacy of social institutions. Their goal was to influence these institutions which:

create, perpetuate or exacerbate personal waste and misery...the family, the schools, social agencies, the courts, industrial organization, community life, the legal and governmental structure and the economic order. 35

Advocates of the new community mental health movement felt it would bridge the gap between the two approaches. The new movement would integrate personality dynamics and sociodynamics by linking the individual's problem with his social situation.

The new centers reflected the shift of emphasis in human behavior studies from one solely on the individual to one that focuses on the individual as an integral part of his family and the community. In Perspectives in Community Mental Health, Herbert Schulberg wrote that in our society:

the family is the basic social unit. Each family will. have its unique pattern of interaction. Evaluation and treatment, if geared to this natural social unit, would not only avoid many of the handicaps of partial and incomplete service; it would facilitate the resolution of the emotional and social problems not just of the patient but of the family members, and lead to a realignment of family patterns of interaction, thereby facilitating progressively more favorable adjustment. 36

Nathan Ackerman recognized that the community mental health movement had much in common with family therapy. Family therapy had the same potential for joining: 
the issues of social and mental health. It supports the values of moving mental health services out of the hospitals and placing them in the center of the community. It furthers the principle of treating the individual's emotional disturbance within his natural environment. It links the psychological disorders of the family and the community. 37

Family therapy would be particularly appropriate to outpatient services.

The community mental health and family therapy movements joined forces over the issue of training new mental health workers. During the early sixties there was a recognized manpower shortage. Since training professionals in traditional methods took years, new methods were sought. Family therapy provided one solution. It was a relatively new modality not yet sufficiently established to be included in the curriculum of most training institutions. Workshops and other brief training approaches in family therapy were used to train many of the new professionals needed to man the new mental health centers.

Two psychiatrists claim that as a result:

the family therapy systems approach was rushed into premature prominence as the single most important psychotherapeutic approach...because (it was) a new technique with a lack of traditional and timetested Timitations. 38

They further state that the training inadequately prepared workers to meet the needs of children. Brief training resulted in some therapists preferring:

to see 'the whole 'family' as existing without those members who have not yet reached a certain level of development which allows them to express themselves verbal1y. 39 
Whatever the reasons, children are in fact being excluded from treatment in mental health clinics, at least in the State of Oregon.*

The two psychiatrists were not opposed to family therapy. Indeed, the thrust of their remarks was that family therapy was a valid approach and that child psychiatry departments should include training in family therapy in their curriculum. In the opinion of the researchers involved in this study, adequate training in graduate schools must be provided to meet the needs of all those who are presently practicing family therapy: general practitioners, pediatricians, psychologists, social workers, counselors, nurses and clergymen as well as psychiatrists and psychoanalysts.

\section{d) FOCUS ON TREATING THE FAMILY SYSTEM}

Interaction of the above forces eventually enabled therapists to understand that the family could best be seen as part of a larger social system. As the focus shifted from the individual to the individual and his relationships, to the family as a system, the problem arose of describing and conceptualizing the family relationships. Family therapists started working without a single theoretical and conceptual framework. As a result, they tended toward two orientations: 1) a psychoanalytic approach and 2) an orientation based on concepts derived from general systems theory which includes both communication and information theory.

*The MED Program Division of the Oregon Mentar Health Department has statistics documenting this fact. 
The interest in studying family interactional and transactional patterns and in working with whole families rather than individuals, took place simultaneousiy in many centers in the United States and in England. Teams of clinician-investigators worked independently without the knowledge that others were working along the same lines. Many of the early pioneers were psychiatrists who treated families where there was a disturbed individual or a problem child. Few of these early experimenters reported on their results, however, because of the "strong Freudian tradition which dictated treating only the identified patients." 40 Gradually other specialists, many oriented in general systems approaches, began experiments studying and treating whole families.

Curiously enough, Dr. John Bell's mistake about the work of Dr. John. Bowlby is responsible for breaking the ban against reporting on results of experiments with families. Apparently Bell misunderstood Bowlby's "account of experience with families" thinking that Bowlby meant he treated the family unit. Bell's report based on this misunderstanding was widely circulated and as a result, the early experimenters began reporting their findings.

As stated previously, one of the earliest supporters of family therapy was Nathan W. Ackerman, a child psychiatrist, who believed that:

the diagnosis of pathology must involve the assessment of the internal organization of the family, parental roles, child-rearing practices and how they are integrated at each step of the child's development. 41 
In 1957, Ackerman founded the Family Mental Health Clinic in New York City which became the Family Institute in 1960, the first of its kind in this country. Around the same time, his first book, Treating the Troubled Family, was published. Throughout the country other family institutes and centers came into existence quite independently: Murray Bowen and Lyman Wynne began working with families in different divisions of the National Institute of Mental Health. In 1957, "Boszormenyi-Nagy organized and directed the Family Therapy Project at the Eastern Pennsylvania Psychiatric Clinic which investigated the potential of a psychoanalytic approach to family therapy. "42

Don Jackson--who coined the term conjoint family therapy--and others such as Gregory Bateson, Jay Haley and Virginia Satir working in the Mental Research Institute in Palo Alto and elsewhere, studied the family, using systems and communication theories. ${ }^{43}$ According to Satir:

the major treatment tool in family therapy is the application of concepts and procedures relating to interaction and communication... The analys is of a symptom starts with an analys is of communication and a documentary of the outcome. Then comes the exploration of the family system, which makes explicit the rules for maintaining the system and points out the individual processes which implement these rules. 44

Finally, in 1962, the Institutes in Palo Alto and New York jointly founded Family Process "in order to facilitate research and theory regarding the family's role in the ideology and treatment of emotional disorders." 45 since the early sixties, publications and institutes proliferated both here and in England. 
According to Jay Haley, the two points of view, one stemming from analytic psychology, the other from general systems and communications theories, share some common assumptions. Haley maintains that an experienced therapist from any orientation:

1) begins to view family therapy not as a method but as a new orientation to the arena of human problems;

2) sees the family system as needing some individual

to express the psychopathology of the system;

3) learns to see the present situation as the major causal factor and the process which must be changed;

4) intervenes as rapidly as possible to take advantage of this opportunity to bring about change;

5) includes himself in the description of the family;

6) tends to interpret destructive behavior in some positive way;

7) tends to feel that any set procedure is a handicap;

each family is a special problem which might require any one of several different approaches. 46

The focus of therapeutic intervention has shifted from attempting to change an individual to work on altering the social environment of his family.

The movement in the direction of family therapy reflects, in part, a general orientation to the nature of human problems based on the premise that individuals cannot be separated from the environment. Man is a part of, not separate from, his environment. This orientation led naturally to the realization that it is frequently more effective to change the individual's living situation than remove him from it or change him. It has also resulted in a weakening of the effectiveness of the medical model in dealing with human behavior:

When the unit shifts from one person to two or more, the medical framework must be abandoned. Psychiatric problems become defined as social 
dilemmas. If the unit is a husband and wife, a mother and child or a whole family, it is not appropriate to think of a disease model, or an illness model, or to think of sickness and health. 47

This, in turn, has resulted in blurring the distinction between the helping professions and raises innumerable questions about training. Teaching takes place in different settings: medical schools, family institutes, workshops, and graduate schools from a wide variety of disciplines. As Haley says:

What has traditional training in a profession to do with this new type of therapy? Since no particular profession has shown superior skill or better training in family treatment, why should one of them have more status or salary than another? 48

At present there are no generally accepted standards of certification or of accreditation, no national organization of family therapists.

In 1962, Murray Bowen said, 'the family movement is currently in what I have called a healthy, unstructured state of chaos.' 49

In 1972, Nathan Ackerman said:

...the ambiguity which currently characterizes this treatment approach lies in the fact that no one can be sure where family therapy begins and. where it ends, or how it articulates with other forms of therapy. But, above a11, there is a conspicuous lack of consensus with respect to the theoretical foundations of this form of intervention. At this stage in the development of family therapy, the possibility that an integrated theory of family behavior and family healing will be achieved in the near future appears remote... One has the distinct impression that each therapist is 'doing his own thing;' but then, even as one watches, he changes his 'thing.' 50

The above point of view represents the approach of some of the professionals trained in the medical model. The attitude of social workers is somewhat different as can be seen in the next part of the literature review. 
B. AN HISTORICAL REVIEW OF SOCIAL WORKERS' ATTITUDES TOWARDS WORKING WITH THE FAMILY

Social work has traditionally been concerned with the welfare of the family in society. In the late nineteenth centruy, Charity Organization Societies were formed to replace public relief and random private charities. In 1911, these societies banded together nationally to form the National Association for Organizing Charity. Many reforms in child care, nutrition, housing and education, came about because of the pressure of the Association. The emphasis was on improving the lot of the family by social reform rather than by aid to individual families.

At the beginning of the twentieth century, these societies began to move into counseling and guidance by what was known as "friendly visitors:"

At that time, the majority of friendly visitors strongly believed that families as well as individuals needed a friend to foster more self-reliance. Friendiy visitors were directing their efforts to educating families and developing within the families activities that would result in more self-help. As an increased awareness of family problems developed, the opinion was expressed that the 'family home' was disintegrating, while others felt that the family was merely readjusting to the changing outside influences. In the past the focus had been more on the 'home' than the family, now more focus was being placed on helping family members adjust to changes occurring within the family. 1

These workers were volunteers and were gradually replaced by salaried workers. As the workers received training and supervision, the social casework method began to assume form. The term "casework" first appeared in a paper read at the National Conference of the National Association for Organizing Charities in the late 1890s, but it was not 
until 1911 that the term became defined as the accepted technique of social work. Aside from the casework method of that era, there were forms of "group work" as the community dealt with working conditions and adult education for their members. Settlement houses provided a place for community members to receive these services.

There was a gradual shift in emphasis and the National Association for Organizing Charities changed its name in 1919 to the American Association for Organizing Family Social Work. Although one eminent speaker of that day is quoted as being "inclined to abolish the family as a unit of interest in social service and replace that unit with the individual," 2 other workers were inclined to believe that the family should be treated as a whole.

The key to prevention and cure of family problems was seen to be in scientific laws and methods. A linear relation was thought to exist between cause and effect; therefore, if the worker could determine the cause of the difficulty, a proper response would cure the dysfunction, producing the desired effect. Mary Richmond became a strong advocate of this idea. She worked closely with David Coit Gilman, president of Johns Hopkins University and the noted physician, William Osler. Mary Richmond's ideas spread and as charity workers began to be caseworkers, the commitment to science became apparent. ${ }^{3}$

As a consequence of World War I, social work began to be available to classes in society other than the poor. The impact of the war reverberated throughout the nation, and people from many economic levels began to look for help to deal with their stress. More and more clients 
were able to support themselves economically and to articulate their needs. Family agencies and child guidance clinics were set up to provide for these new clients.

The experience of working with patients during World War I increased interest in Freud's ideas among social workers, by focusing on the patient's personal meaning ascribed to traumatic events. The social worker became not a doer, as before, but a passive observer:

The psychoanalytic model placed high value on the client's motivation, verbal skills and interest in introspection so that the new psychological procedures were often less effective with clients having problems that were socially perceived rather than self perceived, or clients whose own expectations for help were not understood or met. 4

The caseworker began to incorporate some of Freud's ideas into his practice. The following two ideas became apparent: childhood experiences profoundly influence the individual's later life, and an individual's behavior is a responsive adjustment to his environment. One worker defined the different approach used by the caseworker as follows: beginning near the center of the problem of diseased personality, the psychiatrist bores in and in, while the social worker's sphere of action radiates outward along a 11 the lines of a client's social relations. ${ }^{5}$

The Great Depression forced some changes on the worker and his practice. The financial disaster of the nation forced workers to reconsider the importance of politics and economics on their client's life. And al though workers noticed that different personalities coped with stress differently, the cataclysm of the Depression induced problems unrelated to normal coping strengths. Casework attempted to 
assist the individual while "he struggled to relate himself to his family and community. "6

In the 1940s, social work continued to move to greater examinations of the methods and techniques of its own profession. There was still a lack of distinct frame of reference that would give social work a wide and unique base. There emerged two diverse forms of practice within the casework method--the Functional and Diagnostic Schools. Social work schools were teaching either the Functional (Rankian) or the Diagnostic (Freudian) method. The Diagnostic School had its origins in Mary Richmond's formulations and was structured by Freudian theory. The individual was seen as formed by his early life experiences, and insight was the tool to understanding. A Diagnostic approach to the family is evidenced by this quote from Regina Flesch:

An individual's marriage is, after all, an expression of the individual's total personality. To the marital relationship, based upon early family experience, the individual brings his hopes, fear, and ability to love...Marriage does not alter personal problems but simply provides a new avenue for their expression. The marital discord then is a symptom of other conflicts.7

One worker stated that she felt that "seeing the whole family blurred the autonomy of the individual and the worker was apt to take over the family too completely and overpoweringly. "8

The Functional School was based on a psychology of growth. Given a productive relationship with the worker, the individual could work out his own changes despite prior determining events. The patient would seek help because of anxiety, and anxiety would lead to motivation to change. The relationship between the worker and the client was viewed as the process for growth. 
As the Functional and Diagnostic approaches became more clearly differentiated, the split between the two schools affected both agency practice and graduate training programs. However, as each school enunciated its respective position, there began to be a move toward rapprochement. The development of ego psychology altered the purely intrapsychic orientation of classical psychoanalytic thought and gave the Diagnostic School a more useful social and interactional viewpoint. The Functional School, already attuned to relational concepts, was ready to assimilate some socio-behavioral concepts emerging from the social sciences. And as practices and concepts were tested, each school drew from one another.

By 1946, group work, previously an educational process not clearly part of the social work practice, began to be included in social work training. Some of the uses of group work began to have impact within the family unit. There began to be a definite focus on the family. When family casework accepts as its focus a responsibility to the whole family, it defines a useful uniformity of purpose, structure and method in spite of the large variety of problems and services with which it deals. This responsibility includes an understanding of family organization and the different roles normally assumed by the several members of a family (and helping) the client or clients to re-establish or preserve their different roles within the family. 9

It was during the 1950s that many of the disparate elements of social work coalesced into what could be called a profession. In the early years of that decade, the Hollis-Taylor Report on social work education in the United States was completed. Replacing the apprenticeship idea of learning, the report advocated a generic curriculum of 
education culminating in a master's degree. Several years later the National Association of Social Workers was established. The profession was gaining a clearer definition of itself. These events provided a backdrop and common tool for communicating theory and practice.

During the decade of the $1950 \mathrm{~s}$, the research and literature on families and family process was burgeoning. Many books and papers were published on family work and had an impact on the social work community. 10

Group work was expanding in practice, and more widely reported in the literature. In addition to using group work for educational purposes, practice with groups now'included therapeutic aims as a consequence of its use in this manner in World War II. There emerged a deeper understanding of the individuat in the group as a social being and using the group as a support system.

Group work ideas tied in with the ideas emerging about the family as a unit. The family group is much more durable than other groups, and concepts such as "homeostasis" began to be discussed in the literature. 11 The potential complications in working with the family are many. One worker states:

In connection with the problem of systematically analyzing whole families, it has been said that 'one must accept the fact that the interactions among family members are so numerous that not all of them can be understood and treated. Thus, a way must be found to identify among a large number of interactions those that are crucial positively and negatively, for effective social functioning. 12 
These "crucial positively" transactions within the family form a base from which to build. Workers began to realize that no matter how sick the family, there were still pockets of health within $i t .{ }^{13}$

Caseworkers were learning the concepts of family work from the literature, but were sti11 lacking a conceptual base for the method. In 1957, Dr. Gomberg wrote:

Existing clinical diagnostic tools and classifications focus exclusively on individual personality. Our attempt in casework to encompass the larger whole to include the social factors and the family in our diagnosis, is only partially successful. No diagnostic or conceptual system exists which describes, assesses, or classifies the family configuration, yet this is clearly needed if the diagnosis of the individual is not to be in a vacuum but rather within the context of the social and emotional environment in which he lives, adjusts, fails, or succeeds. We must not choose between a concept of the family and a psychology of the individua 1; it is through a balanced understanding of the interrelatedness between the two that we can achieve the most meaningful understanding and the most effective trea tment. 14

The publication of Dr. Ackerman's book in 1958 offered a comprehensible theoretical approach to the individual within the family, and presented a system for organizing and collecting data on the individual and his family. 15

In the 1960s, social work jobs proliferated as services were broadened to deal with the War on Poverty. The Economic Opportunities Act, expansion of day treatment centers and community action programs were some of the projects involving a wide use of professional social workers. The concept of social systems gave another new conceptual base to the worker. : Viewing the family as a system followed naturally. 
As mentioned earlier, one writer wrote a mini-history of the use of family work at child guidance clinics, as follows:

Ackerman has pointed out the shift in emphasis at child guidance clinics over the past two decades. Influenced by traditional psychoanalysis, early practice in child guidance clinics generally consisted of play therapy; the child was seen individually, and his play behavior and play fantasies were explored in order to learn about conflicts, both conscious and unconscious. However, it became apparent that much of the therapeutic progress was being undone at home, where the environment remained unchanged. Because of this fact, mother gradually was involved in therapy; the child was seen by a psychiatrist and the mother by a social worker. (This was the period of the child guidance movement in which the staff were known as 'mother killers;' they teamed up on the side of the child against the mother.) In time, mothers and children were treated together, first by two different therapists and then by a single therapist. When the parental relationship of a child--particularly a boy child--were being explored, it was impossible to work out the oedipal conflicts without involving the father. Gradually, then, the father was brought into the treatment situation. The whole family was now involved.16

It was during the 1960s that family therapy really began coming

into its own. One worker chalked up the delay to Freud:

The question arises periodically as to why family therapy has not been given its due until recent times. The past lack of interest in family study is all the more curious since in 1936 the Ninth International Congress of Psychoanalys is had as its topic 'The Family Neurosis and the Neurotic Family.' There are many reasons for this state of affairs. Overshadowing all was Freud's influence. He warned repeatedly against involving relatives in treatment. 17

The practice of treating the entire family together runs counter to the American 'tradition' of leaving one's family and striking out on one's own. This tradition stems from two sources, .1) the necessity for leaving the family in order to conquer the frontier, and 2) the need to divorce oneself from tradition and culture related to the 'old world' in order to become Americanized. Many patients entering analysis foresee a successful outcome of therapy as including 'liberation' from the family of origin. 18 
Perhaps workers were hesitant to use family therapy, viewing the family as a system difficult to change. Bardill and Ryan point out the situation as follows:

In genera1, family group casework should provide the family with an opportunity to appraise the need for the changes in the processes of family living. At the very least, treatment should encourage a quality of open and free communication. Through this process family members hopefully will gain a more conscious awareness of the roles they play in relation to one another. Whether the family system gets altered as a result of increased awareness remains a decision that the family alone can make. Most family systems will change only minimaliy and slowly even where treatment seems successful. But, as individual members in a family become more clear about who they are and what they do to one another through various modes of behavior, the consequences of systematic patterns are more realistically assessed and options for change can at least be considered. 19

The caseworker must assess the motivation of the family as well as its capacity to change by perceptive interviewing. One worker stated it in this manner: "If all family members seem to recognize that the experience can be uncomfortable and disarming, as well as inconvenient, and if they would like to try it out in spite of this, the initial prescription is one of positive motivation." 20

The writings in the 1970 s became more specific as to the techniques, advantages and disadvantages of family therapy. No longer was there a search for a definition and theoretical base; family therapy became an option for the treatment of choice. And there were many models available to the worker from conjoint family therapy to network therapy. Most theorists agree that a family crisis is most likely to bring the family to the point of seeking change: "...the family can more often 
be dealt with effectively as a unit because these crises tend to reverberate strongly in the total family."21

When such a crisis occurs, aid must be available quickly to the family. One study published during the 1970s dealt with client perceptions about agency hours, fees, waiting time, etc., in terms of the inability of the agency to meet their needs. ${ }^{22}$ The findings of the 1970 study do not accord with the data collected in 1976 in Portland, Oregon.

However, there are some important contraindications to family work, and the literature in the 1970s has recognized some of them. The family on the brink of divorce, one family member in therapeutic treatment elsewhere, a hostile member impenetrable by the worker, or persistent refusal of one member to attend the sessions can signal a poor prognosis for working with the family unit.

Aside from the above considerations against using the method of family therapy, the quality of worker-client interaction seems to remain all important. One social work researcher examined the effect of the counselor on the outcome of family therapy and discovered that the concern and support of the social worker is a more important treatment variable than the substantial number of treatment resources and intervention patterns examined. ${ }^{23}$ It would seem that the worker trained in family therapy would find it a useful and exciting modality. The question remains why it is so little practiced by social workers working in family agencies today in the 1970s. 


\section{CHAPTER III}

\section{METHODOLOGY}

Intensive reading in the literature of family therapy as well as interviewing some of the social workers in the community who are actively practicing family therapy revealed some of the difficulties in defining precisely what was meant by the term family therapy. Historically social workers have maintained an interest in family welfare but during the last forty years the focus has been primarily on serving the family member rather than the total family unit. It seemed as if family therapy covered a multitude of techniques and approaches each of which represented the orientation of the therapist rather than any single theoretical base. It was decided to find a definition that would accurately define the approach presented in the family therapy workshops both researchers had attended. ' The definition provided by the Family Service Association of America seemed most appropriate:

Family treatment is the process of planned intervention in an area of family dysfunctioning. . .centered upon the dynamic functioning of the family as a unit and some form of multiple interviewing is the primary treatment technique. Shifts to other treatment techniques. - .are related to the emergence of new diagnostic data or treatment developments, and are undertaken in the context of the total family treatment goal. Since the goal of treatment requires focus on the family, some form of multiple interviewing remains the major treatment technique. (italics provided by researchers) 2

From the preliminary investigation three hypotheses were eventually developed: 1) agency support of family therapy increases the likelihood 
that social workers will use this modality; 2) agency-based social workers are practicing family therapy as defined in the Casebook in Family Diagnosis and Treatment published by the Family Service Association of America in 1965; and 3) special training in family therapy increases the likelihood that social workers will use this modality.

The next problem was to decide whether to gather information through personal interviews or mailed questionnaires. The former would limit the size of the study; the latter would be less personal The researchers felt that personal interviews with social workers would be more congruent with the study than would the less personal method of mailed questionnaires. Personal interviews would provide better insight into the workers' attitudes and experiences. Furthermore, any confusion in terminology would be more easily clarified through this approach.

To provide as much information as possible, it was decided to develop a questionnaire including both specific structured questions and openended questions. It was also decided to frame the questions around each of the three hypotheses. Questions about agency support included asking whether the agency was public or private. Information was also asked about the fee arrangements, hours for counseling, waiting lists, home visits, evaluation of agency's interest and the type of available supervision and training. With a reference to family therapy written by Grace Coyle in mind--"What goes on in practice is difficult to determine."-the researchers decided to elicit information about practice techniques in a number of different ways to cross check the information. ${ }^{3}$ Three separate questions were framed: one directly asked the workers whether or 
not they considered themselves family therapists; a second asked which mode of interviewing--individual, mother and child, father and child, or whole family--they used; a third asked whether they felt that their "personal style of working with families would accord" with the researchers" definition. Questions about worker training were framed to elicit information about when and where the workers received their degrees, the type of training they had had both in school and after earning their degrees, and the relationship between the type of training they had received and the type of practice they performed. A fourth category of questions evolving out of the personal interest of the researchers but unrelated to the specific hypotheses was also prepared. These were framed for the most part around the workers' evaluation of their training and knowledge of local and national training programs. A copy of the questionnaire is in Appendix $A$.

To refine the questions, clinicians directly involved in practicing family therapy were asked to respond to the questionnaire. This pretesting process resulted in some revisions for the following reasons: The Family Service Association of America (hereafter referred to as FSAA) definition of family therapy was long and involved. The interviewees were frequently confused; the interview was prolonged and at times awkward. It was decided to type out the definition and to ask the interviewee to read the typewritten definition while the researcher read another copy out loud. The phrases "family as a unit" and "multiple interviewing" were underlined for emphasis. It was also decided to save the question which asked. whether or not the method of practice was in accord with the definition until the very last. It was felt that if the definition were shown in the beginning, it would tend to bias answers related to personal practice. 
approach. It was hoped that this would prevent the workers from being influenced by the researchers' point of view. It was also decided to type out a card with the four categories--"none," "some," "most," and "a $11 "--$ used in three of the questions. This card was given to the inter-. viewee at the beginning of the interview with a simple explanation that it would be used in three (3) different questions.

The section labeled "Family-Personal Problems" in the booklet Where to Turn, a directory of community services published by the TriCounty Community Council, was used to select agencies to survey. To provide a reasonable limit, only agencies from Multnomah County were selected. Those agencies which did not provide direct counseling services-The Red Cross and the Suicide and Personal Prevention Crisis Services-were eliminated. The list of agencies used is included in Appendix B.

A letter was drafted and sent to the directors of the agencies informing them of the intended study and asking for permission to telephone them within the next week to arrange an interview with one of their workers who was "involved in direct service to families." All were cooperative. One director asked to be interviewed personally. Interviews were scheduled by telephone and were held between October 18 and November 25, 1976. Each interview ranged in time from one-half an hour to one hour. A copy of the letter is in Appendix $C$. 


\section{CHAPTER IV}

\section{FINDINGS}

Since the interview questions were formulated around the three hypotheses, the findings were organized in the same manner.

Hypothesis \#1. Agency support of family therapy increases the 7ikelihood that social workers will use this modality.

The agencies had the following characteristics. Eleven (55\%) of the agencies were private, non-profit organizations receiving public funds; seven (53\%)were public; two (10\%) were private, nonprofit organizations receiving no public funds.

The fee structures ranged from a sliding scale based on the clients' ability to pay to no fee at a11. Thirteen $(65 \%)$ of the agencies had a sliding scale; six (30\%) had no fees for their clients; one $(5 \%)$ had a set fee and sliding scale.

Waiting lists for treatment of families ranged from none to as long as one and one-half months. Fifteen (75\%) of the agencies had no waiting lists at all. Five $(25 \%)$ had a waiting list although of the five only two had waiting lists longer than three weeks.

A11 the agencies saw clients during the traditional business hours of the working day starting between eight and nine in the morning and ending at four or five in the evening. Agencies offered a variety of other times available for counseling. Thirteen (65\%) were open regularly in the evenings ranging in time from one to three evenings a week. A few agencies offered counseling service by appointment only 
in the evenings. Six (30\%) of the agencies offered twenty-four hour service. All of these were residential care facilities. It was impossible to categorize some agencies; these were the kind that offered a wide variety of service and the time available for counseling depended on the type of service offered.

Home visits were available in sixteen agencies $(80 \%)$ but not available in four (20\%). Most workers said they preferred working in the office. One worker said she "sets it up to get invited to dinner." She schedules a dinner time appointment and the family frequently invites her to dinner. She stated that observing the family at dinner provides a great deal of useful information. When asked about agency interest in family therapy, sixteen $(80 \%)$ described their agencies as "very interested" while three (15\%) said "moderately," and one (5\%) said "slightly." (See Figure 1. Sample Size and Characteristics 1976.)

Investigation of training opportunities or on-the-job supervision covered five different forms: utilization reviews or case conferences, stipends for attending workshops, consultants on the staff, and such training devices as video-tape machines and one-way mirrors. Of the twenty agencies three (15\%) had none of the above available for their workers. Two of these were private agencies, one a public agency whose funds have been drastically cut in the last few years. Fifteen (75\%) of the agencies provided some form of utilization review or case study al though the time-span. ranged broadly from every week to every six 
FIGURE I. SAMPLE SIZE AND CHARACTERISTICS (1976)

\begin{tabular}{|c|c|c|c|c|c|c|c|c|c|c|c|c|c|c|}
\hline $\begin{array}{l}\text { AGENCY } \\
\text { STATUS }\end{array}$ & No. & $\begin{array}{l}\text { FEE S } \\
\text { Sliding } \\
\text { Scale }\end{array}$ & $\begin{array}{l}\text { RUCT } \\
\text { Set } \\
\text { Fee }\end{array}$ & None & $\begin{array}{l}\text { WAI } \\
\text { LIS } \\
\text { Yes }\end{array}$ & & $\begin{array}{l}\text { HOME } \\
\text { VISI } \\
\text { Yes }\end{array}$ & & $\begin{array}{l}\text { HOURS } \\
\text { Eves. }\end{array}$ & Wknds. & 24 & $\begin{array}{l}\text { AGENC } \\
\text { INTER } \\
\text { Sligh }\end{array}$ & Tod. & Very \\
\hline PUBLIC & 7 & 4 & 1 & 2 & 1 & 6 & 5 & 1 & 4 & 2 & 1 & 0 & 1 & 5 \\
\hline $\begin{array}{l}\text { PRIVATE, } \\
\text { NON-PROFIT } \\
\text { WITH } \\
\text { PUBLIC FUNDS }\end{array}$ & 11 & 9 & 0 & 2 & 4 & 7 & 11 & 1 & 7 & 3 & 5 & 0 & 2 & 10 \\
\hline $\begin{array}{l}\text { PRIVATE, } \\
\text { NON-PROFIT } \\
\text { NO } \\
\text { PUBLIC FUNDS }\end{array}$ & 2 & 0 & 0 & 2 & 0 & 2 & 0 & 2 & 2 & 0 & 0 & 1 & 0 & 1 \\
\hline $\begin{array}{l}\text { TOTAL } \\
\text { OR. } \\
\text { AVERAGE }\end{array}$ & 20 & 13 & 1 & 6 & 5 & 15 & 16 & 4 & 13 & 5 & 6 & 1 & 3 & 16 \\
\hline
\end{tabular}

* The workers were asked to assess their. agency's interest in family therapy. 
months. One worker said, "We are supposed to do it every ninety days. In practice it is done only once in six months." Ten agencies (50\%) had a paid consultant on the staff and nine (45\%) had video tape available for training while seven (35\%) had one-way mirrors or other training devices of a comparable nature. (See Figure II.Relationship of Agency Support to Practice of Family Therapy 1976.)

Hypothesis \#2: Agency-based social workers are practicing family therapy as defined in the Casebook in Family Diagnosis and Treatment published by the Family Service Association of America in 7965.

The workers were asked whether or not they considered themselves family therapists. Eleven (55\%) indicated they were while nine (45\%) indicated they were not. Over half described themselves as family therapists.

The workers were next asked whether their approach was designed to a) elicit expressions of family feeling, b) restructure behavior patterns or $c$ ) were a combination of both approaches. A11 the workers responded that they followed a combination of both approaches although one indicated she had a bias towards eliciting expressions of feeling, and another said she "restructured family behavior patterns only because she is employed by a residential care facility which uses a behavioral modification approach."

Workers were next asked to identify their treatment modality solely on the basis of interviewing techniques: how often they interviewed individuals, how often they interviewed mother and child or father and child, and how of ten they interviewed the entire family. 
FIGURE II. RELATIONSHIP OF AGENCY SUPPORT*

TO PRACTICE OF FAMILY THERAPY

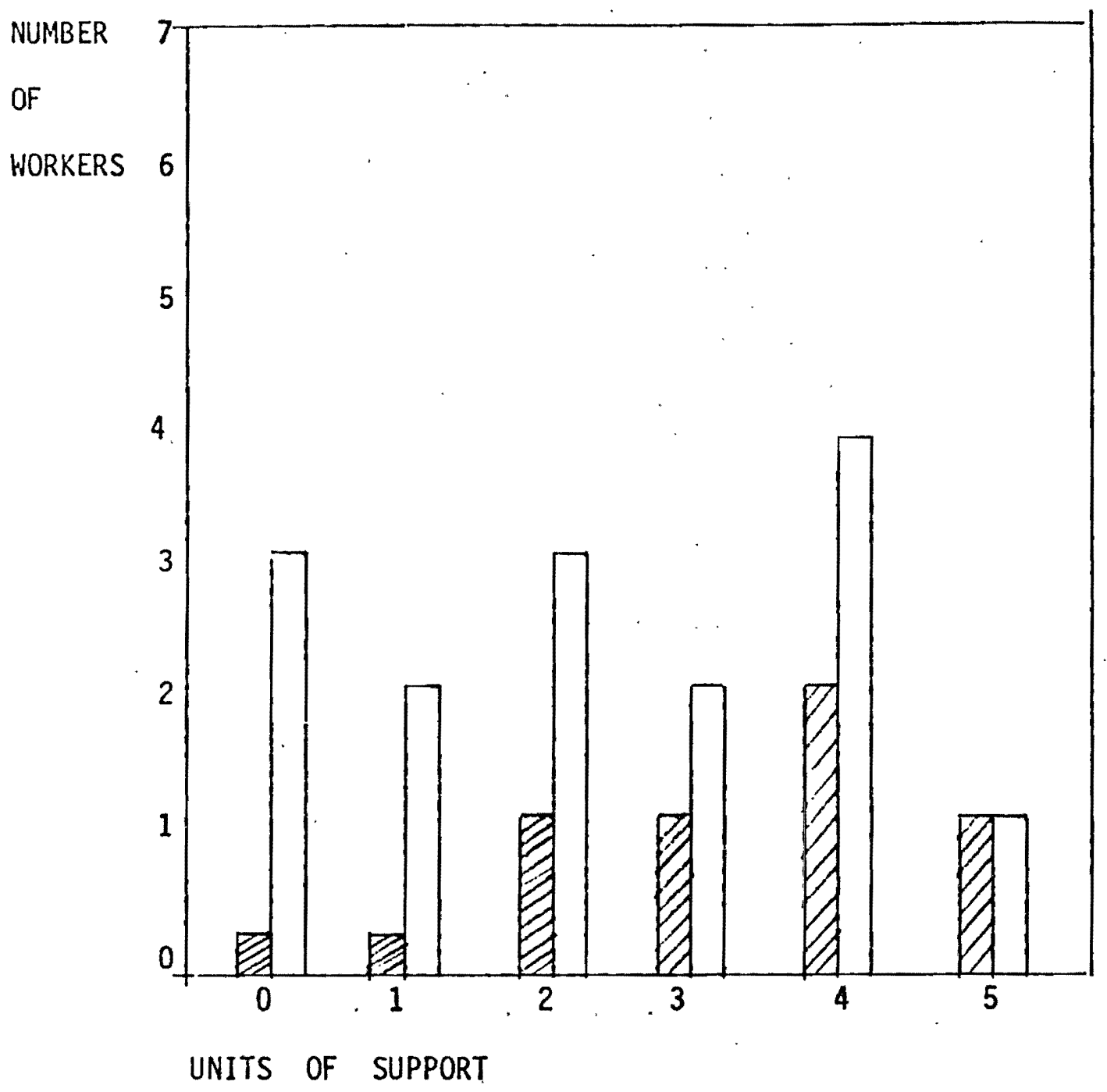

* Units of support include training and supervision.

1. utilization review

2. psychiatrist on staff

3. video tape

4. stipends for training

5. one way mirror 
The assumption was that only those workers who responded "a11" or "most" of the time would qualify to be labeled family therapists in accordance with the researchers' definition. Five (25\%) indicated they interviewed the whole family "a11" or "most" of the time. One worker said she interviewed the family as a unit for several visits to assess the appropriate treatment but did not continue to work with the family as a unit "most" or "al1" of the time. Therefore she was not included in the group labeled family therapists.

Although over half of the workers indicated they were family therapists, oniy one quarter of the workers interviewed actually practiced family therapy in accordance with the definition established by the Family Service Association of America.

As indicated in the methodology, an additional question designed to elicit the workers' attitudes about family therapy was asked at the end of the interview. The workers were asked to read the definition of family therapy provided by the Family Service Association of America. The definition stressed two ideas: treating the family as a unit and multiple interviewing. These two ideas were underlined for greater clarity on the definition. The workers were asked whether or not their personal style of working with families would accord with the definition presented to them. The categories "none," "some," "most," and "a11" of the time were used. One worker's response failed to fit into any of the categories so data are based on nineteen (19) workers on this question only. Again, the assumption was that the definition used would require workers to answer "a11" or "most" of the time in order to 
qualify as family therapists. Out of the nineteen social workers included in the data, twelve (63\%) indicated their style would accord with the definition while seven (37\%) indicated their style would not. (See Figure III. Proportion of Social Workers who label selves family therapists and proportion who practice according to FSAA definition.)

One final question about the workers' practice asked whether or not they worked with a co-therapist and used the categories "none," "some," "most," or "all" of the time. Of the twenty workers interviewed, only five $(25 \%)$ stated they did no co-therapy. Twelve $(60 \%)$ stated they did "some" co-therapy. Two (10\%) stated they practiced with a cotherapist "most of the time" and one or 5\% said she used co-therapist "a17" of the time.

Hypothesis \#3: Special training in family therapy increases the likelihood that social workers will use this modality.

Workers were asked to state their degree, the date they received it, and the institution from which they had graduated. Of the twenty people interviewed, fourteen (70\%) had earned their MSWs, six (30\%) had not. Half of all the interviewed workers had been graduated from Portland State University. The earliest date of graduation for workers earning their MSWs was 1950, the latest 1975, a span of twenty-five years. The earliest date of graduation for workers without their MSWS was 1943, the latest 1977, a span of thirty-four years. 1969 was the median date of graduation for both those with and without a Masters degree. The mean number of years since graduation for all workers was seventeen; the mean for those with an. MSW was twelve years. 
FIGURE III.

PROPORTION OF SOCIAL WORKERS WHO LABEL SELVES FAMILY THERAPISTS

AND PROPORTION WHO PRACTICE ACCORDING TO FSAA DEFINITION.

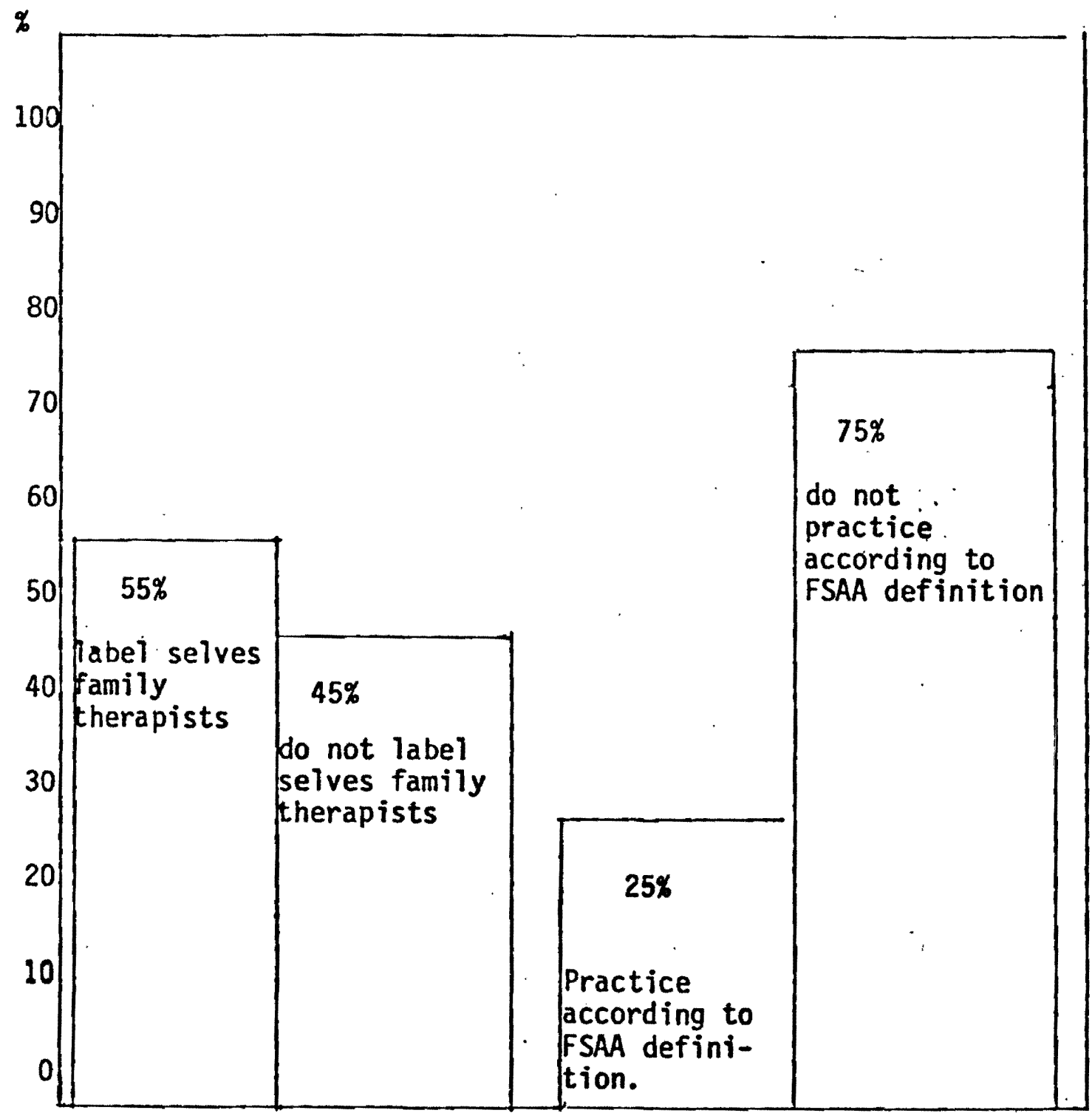


The next question asked about special training in family therapy while in undergraduate or graduate school. Only three (15\%) of the workers had received any special training in family therapy during school. One of these had been made responsible for the treatment of a family during one entire year of graduate school. These three workers had received their degrees in 1970, 1972 and 1974 respectively. A11 labeled themselves family therapists. One was an administrator not involved in practice; another met the criteria established by the interview method in the definition and one did not. Three social workers $(15 \%)$ indicated they had received useful training during field placement while in graduate school. Two of these went through graduate school during the seventies, one during the fifties. Six $(30 \%)$ indicated that al though they had no special training, some of their classwork had been "useful." Nine (45\%) of the workers had no special training in family therapy while in school.

Workers were then asked about special training in family therapy since graduation. Six $(30 \%)$ had received no training since graduation. Eight (40\%) had attended one workshop only. Two (10\%) had attended two or three workshops. Four (20\%) had attended four or more workshops. One of the four who had attended four or more was an experienced coleader of family therapy workshops. (See Figure IV. Relationship between year of graduation and family therapy practice 1976.)

Questions unrelated to hypotheses

When asked whether or not their training in family therapy affected their feeling of competency while working with families, sixteen (80\%) 
FIGURE IV.

RELATIONSHIP BETWEEN YEAR OF GRADUATION AND FAMILY THERAPY PRACTICE, 1976.

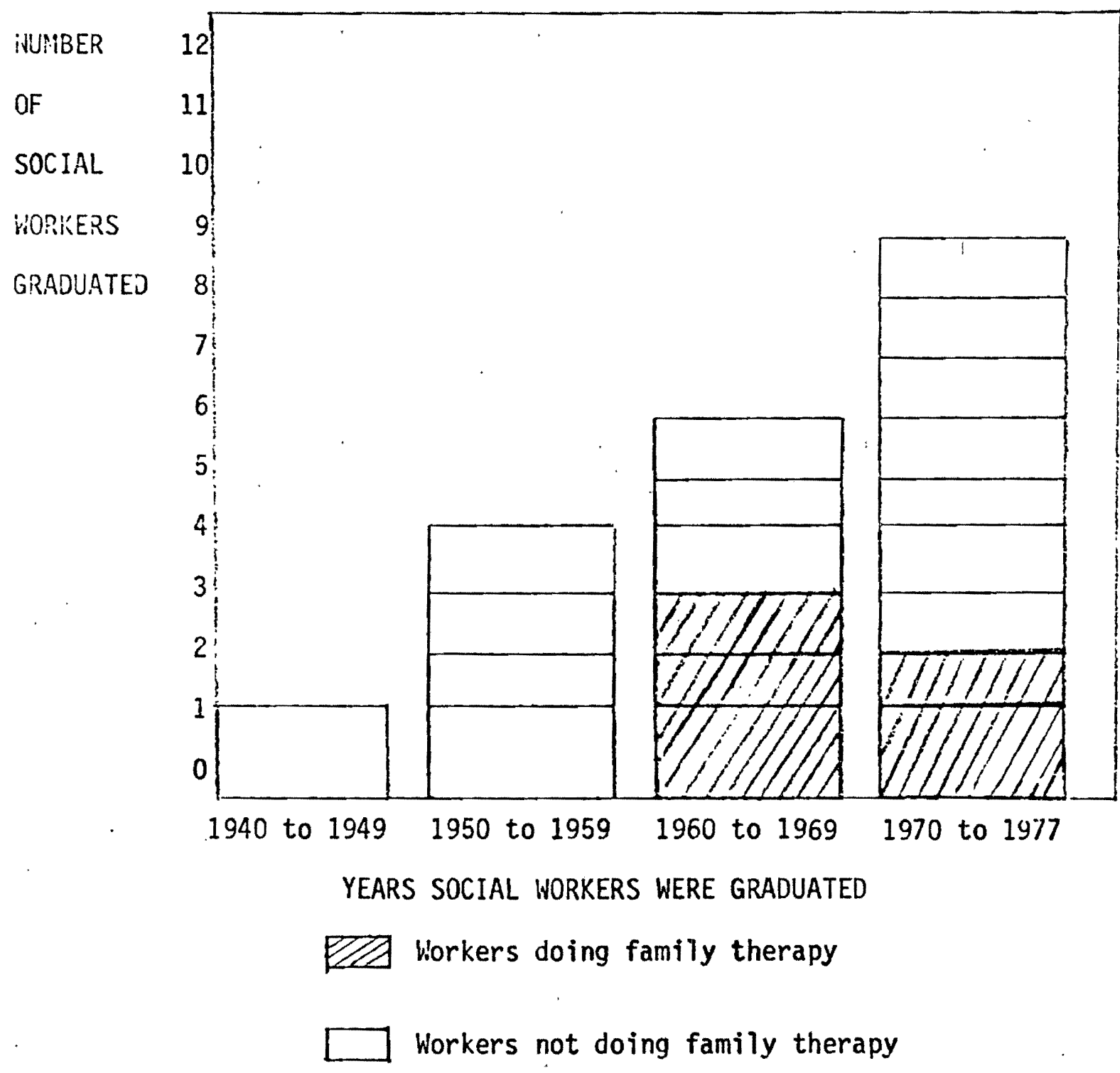


said it did, three (15\%) said their training did not affect their feeling of competency. One $(5 \%)$ had no training in family therapy. One worker said that she felt the experience of actually doing family therapy was more effective than her training. Another commented that the training highlighted her awareness of the inadequacy of the facilities in her agency for working with families. She would have liked to have done family work more often and would have done so had there been adequate facilities. One felt that readings about family therapy in the literature had been of more help than his training. Another felt that the training added another dimension to her treatment skills: "I find family therapy more stimulating and difficult. I think it's powerful for kids to hear what their parents' childhood was 1ike." Another commented that she had a "better conceptualization of families as systems, and it gave me an awareness of my own nuclear family dynamics." Another said that "it helped provide a working-theory base for me. It gave me feedback on my own style and a chance to practice and be observed." Respondents were also asked whether their training in family therapy influenced them to work more often with families than with individuals. Fifteen (75\%) of the workers answered "yes;" two (10\%) said their training had not influenced them to work more often with families, and one (5\%) said she could not answer the question. One (5\%) had had no training. One of the twenty $(5 \%)$ answered in ways that could not be categorized into a "yes" or "no" answer: "I've been around so long, seen so many waves, ebbs and flows..." 
When asked what was the most helpful in their training in family therapy, four (20\%) workers stated that the concept of the family function was the most helpful. Three (15\%) indicated they found the actual practice and ongoing supervision the most helpful. Two (10\%) replied that their general school training in social work was most helpfut ${ }^{\prime}$ One interviewee (5\%) refused to answer the question, and one (5\%) could not answer since she had had no training. The comments ranged from "learning to pick up body cues and unspoken signs," to "change is possibie by a contract and decision. Parents do the best they know how at the time," to "seeing it being done" and "endorsement to go ahead with it'."

When asked what was least helpful in family therapy training, seven (35\%) interviewees could find nothing that fit into the category "least helpful." Four (20\%) indicated the didactic material along with assigned readings was least helpful. One $(5 \%)$ indicated that the behavioral modification orientation was least helpful. One (5\%) commented that "the bias that all families should be treated as a unit" was least heipful. One interviewee (5\%) responded that the "warm up jobbies" were least helpful; another (5\%) that the "jargon" was least helpfut.

When asked whether or not they had attended any professional meetings or workshops in family therapy during the last year, ten (50\%) said they had not; nine (45\%) said they had, and one (5\%) had attended none.

When asked where they would go for further training in family therapy if the opportunity arrived, four (20\%) said they did not know; 
eight (40\%) said they would go for further training in family therapy if the opportunity arrived, four (20\%) said they did not know; eight $(40 \%)$ said they would go to the Western Institute for Group and Family Therapy in Watsonville, California. Two (10\%) mentioned Portland State University and three (15\%) mentioned Nancy Kosterliz and Jack Tovey who are local family workshop trainers. Other names mentioned were Irv Polster, Salvador Minuchin and Harry Aponte.

When asked whether they knew. any local training programs, fourteen $(70 \%)$ of the interviewees knew about the Kosterlitz-Tovey workshops; three $(15 \%)$ were unaware of any local programs. Other names mentioned were Nan Narboe, Dr. James Shore, Lutheran Family Services and Columbia Pacific. 


\section{CHAPTER $V$}

\section{CONCLUSIONS AND INTERPRETATIONS}

The type of agency and kind of service offered as well as worker training and supervision opportunities affect the first hypothesis: agency support increases the likelihood social workers will practice family therapy. On the basis of this study, it would appear that private non-profit agencies not receiving public funds would be less likely to offer family therapy than would other types of agencies. They would have limited funds which would effectively control the type of service offered and the kind of professionals employed. The two private non-profit agencies not receiving public funds included in this study specialized in providing food, clothing and shelter. Counseling was minimal, usually consisting of one visit only. These two agencies relied heavily on volunteer workers. One depended entirely on volunteers; the other had only two paid counselors on its staff. Both directors were college graduates with minimal graduate work and no special training in family therapy. One, an administrator doing no direct service, asked to be interviewed despite the letter requesting a worker involved "in direct service to families." She quite frankly admitted her agency was not doing family therapy "as such." She did not label herself a family therapist. The other director who was involved in counseling labeled himself a family therapist although he failed to meet the standards based on the FSAA definition. 
Private non-profit agencies receiving funds do so through contracts made with public service agencies such as the Children's Services Division and Public Welfare. Apparently public agencies are recognizing the need for this type of counseling although they are unable to offer it themselves; private agencies might be unable to offer it were they not to receive public funds.

One public agency, started in 1966 by the Office of Economic Opportunity as a pilot project designed to pull together four neighborhoods, is an interesting exception. This agency is community based and has a board of directors elected by residents from the residents in the area. The worker from this agency met the standards the researchers had established, labeled herself a family therapist, and was the only worker to state that her practice approach agreed with the FSAA definition "all" of the time. She also indicated that she practiced a great deal of family therapy. Interestingly enough, her agency was one of the few that had a waiting list.

Another determinant is the type of service offered. Some of the agencies offered a wide variety of services. Whether the worker was doing family therapy was determined more by the assignment than on overall agency policy. A11 agencies provided some counseling services although the range varied from one visit to long-term treatment. Eight of the agencies also provided some form of placement including placing children who were having family problems in foster homes or residential care facilities as well as placing adults or families with a variety 
of problems in temporary or permanent shelter facilities. Two agencies worked with adoptions and two provided all the services mentioned plus "confidential maternity services" and some form of educational assistance.

The study showed that workers assigned to residential care facilities appear to be less likely to work with whole families than do those working in outpatient clinics or agencies. A child placed in a residential facility is out of the family; contact with the family is on a visiting basis only. Counselors working with these young people are less likely to work with the child and his family than with the child alone. Five of the agencies canvassed had residential care facilities. Three of the workers interviewed were assigned to this type of facility. All three labeled themselves family therapists. A11 felt they practiced in accord with the FSAA definition. None, however, met the standards established by the researchers to meet the FSAA definition.

There seems to be no relationship between the type of agency support in terms of availability of time and costs of services and whether or not family therapy was offered. Agencies are open during hours convenient for al1 members of the family including working parents and school children and at costs reasonable for all income levels. Furthermore, home visits are available for those unable or unwilling to go to an agency. If the workers were interested in practicing family therapy, agency policy, in this area at least, should have no impact. 
On the other hand there seems to be a relationship between the type of available supervision and training and the type of therapy practiced. Al1 therapists practicing family therapy according to the FSAA definition worked in agencies having at least two types of support. One agency provided the full range of supports, two provided four out of the five supports and only one provided two out of five supports. All agencies provided utilization reviews or case presentations.

The hypothesis that agency-based social workers are practicing family therapy as defined in the Casebook in Family Diagnosis and Treatment proved to be untrue. It appears that Grace Coyle's statement--"What goes on in practice is difficult to determine"--is valid. The three different questions aimed at eliciting information about practice techniques provide clues to the difficulty. Only five of the twenty workers met the standards established by the researchers to meet the FSAA definition. Four out of these labeled themselves family therapists. One whose training on a graduate level was unique--she had worked with a family for an entire year--and who had a modest amount of postgraduate work did not label herself a family therapist. All five agreed that their mode of practice coincided with the FSAA definition; all five stated that they worked with a co-therapist "some" or "most" of the time. (See Figure V. Characteristics of social workers practicing family therapy.)

It is the researchers' assumption that the seven workers who state they are practicing family therapy but fail to meet the FSAA definition may, 
FIGURE V. CHARACTERISTICS OF SOCIAL WORKERS PRACTICING FAMILY THERAPY

\begin{tabular}{|c|c|c|c|c|c|c|}
\hline No. & YEAR OF GRADUATION & SEX & DEGREE & TRAINING IN SCHOOL & WORKSHOPS SINCE SCHOOL & AGENCY STATUS \\
\hline 1 & 1966 & $\mathrm{~F}$ & BA & NONE & $3+$ WORKSTHOPS & PUBLIC \\
\hline 2 & 1969 & $F$ & MSW & NONE & CONSIDERABLE & $\begin{array}{l}\text { PRIVATE } \\
\text { PUBLIC FUNDED }\end{array}$ \\
\hline 3 & 1972 & $F$ & MSW & CONSIDERABLE & 3+ WORKSHOPS & $\begin{array}{l}\text { PRIVATE } \\
\text { PUBLIC FUNDED }\end{array}$ \\
\hline 4 & 1977 & $M$ & $B A$ & NONE & $3+$ WORKSHOPS & $\begin{array}{l}\text { PRIVATE } \\
\text { PUBLIC FUNDED }\end{array}$ \\
\hline 5 & 1969 & $M$ & MSW & NONE & $3+$ WORKSHOPS & $\begin{array}{l}\text { PRIVATE } \\
\text { PUBLIC FUNDED }\end{array}$ \\
\hline
\end{tabular}


in fact, either be practicing in a manner that fails to fit the narrow FSAA definition, or may be practicing "family-oriented" therapy as described in the introduction to the literature review. The questionnaire was not designed to tease out the difference.

The discrepancy in labeling most likely results from confusion surrounding the FSAA definition. The researchers assumed, for example, that the term "multiple interviewing" meant that workers would interview in their office at the same time, all members of the family; it could also mean that the workers met with all members of the family but interviewed them separately or in different combinations at different times as the need arose. Even more confusing is the word "family" which means different things to different people. The researchers questioned the workers about their interview mode asking them to identify whether they interviewed an individual, a mother or father and child, or whole families. A mother and child or father and child could, however, constitute the entire "family unit" or "whole family." Single parent families are common in today's world. A marital pair without children could also be considered a "family unit" since more and more couples are deciding not to have children. Furthermore, what constitutes a family unit is dependent on the approach of the individual therapist. One of the leading family therapists, Murray Bowen, has moved from working with whole families to working almost exclusively with parents. 1 He has contributed a great deal to the literature; workers reading his material might well be influenced by his approach. Other therapists insist that family therapy occurs 
only if there is a minimum of three people--at least the two parents and one child. Some therapists work only with the nuclear family, others with all members of a family living in one dwelling, yet others with the extended family. Multiple-impact therapy and network therapy are often included under the general heading of family therapy. In fact, it would seem that in view of the proliferation of techniques subsumed under the general term family therapy during the past ten years, the FSAA definition published over a decade ago may have been too narrow and restrictive. Whether or not interviewed workers were aware of these definitional problems is unclear; the confusion may, however, have made the data inaccurate.

The third hypothesis--that special training in family therapy increases the likelihood that social workers will use this modality-appears to be true. All five workers had attended more than three workshops in family therapy. Of even more interest is that a11 workers had attended the workshops after having completed their academic careers. In fact, it would appear that even more important than the degree the workers have received is the number of workshops they have attended. Only three out of the five workers who practiced according to the standards the researchers established to meet the FSAA definition had received their MSWs. A11 workers practicing according to the FSAA definition had received their training after 1966--during the past eleven years.

Additional tentative conclusions can be drawn. Workers are apparently more willing to share the treatment process with another 
professional now than they were in the past. Fifteen out of the twenty therapists used a co-therapist at one time or another. The singleminded focus on individual therapy, so prevalent during the first forty or fifty years of this century, no longer exists. A major barrier to the treatment of the entire family--the fear of contaminating the transference--is gone. Conjoint therapy is a recognized technique.

It is difficult to determine precisely how much family therapy is practiced in agencies in this community because of the narrowness of the FSAA definition used by the researchers. It is of interest, however, that the one public agency using family therapy extensively is small, and community based and community controlled. Since neighborhood residents are actively involved in running the organization, it seems natural that they would know what services are offered and make use of them. This suggests that educating the public about family therapy would increase its use of this modality.

A review of the three hypotheses about the use of family therapy by agency-based social workers in this community reveals that:

1) when agencies provide supervision and training opportunities, workers are more likely to use family therapy;

2) while agency-based social workers are apparently not practicing family therapy according to the strict definition of the FSAA, many may, in fact, be practicing some form of family therapy;

3) special training in family therapy does indeed increase the likelihood that agency-based social workers will use that modality. Unquestionably interest in family therapy has grown during the last decade. The 1971 publication by Glick and Haley--Family Therapy 
and Research: An Annotated Bibliography--is a testimony to the flood of material published on the subject. So is the proliferation of workshops and training institutes. The researchers are convinced that family therapy, if defined broadiy, has the potential for being one of the best tools a therapist has to effect change and is a powerful means of helping an individual utilize his family as a natural helping system. Acknowledgement of interdependence allows for growth and autonomy to function alongside of support and intimacy. The process strengthens the family unit as well as the individual.

For the above reasons, the researchers feel that schools of social work are behind in their offerings. Schools should offer their students more training in family therapy; the training should include a wide variety of approaches. 


\section{FOOTNOTES}

Chapter I

1. Michael Novak, "The Family Out of Favor," Harper's Magazine (Apri1, 1976), pp. 37-46..

Chapter II A.

1. Robin A.C. Skynner, Systems of Family and Marital Psychotherapy (New York: Brunner/Mazel, 1976), p. 363.

2. Freda Martin, Family Therapy for Individual Therapy (And Vice Versa) (Typewritten paper presented at the Tavistock Institute, London, England, 1975), p. 4.

3. Michael J. Sporakowski and Paul R. Mills, Jr., "What's it All About? An Overview of Family Therapy," The Family Coordinator (January, 1969), p. 63.

4. Nathan W. Ackerman, "The Future of Family Psychotherapy," Exploring the Base for Family Therapy, Nathan W. Ackerman, Frances L. Beatman and Sanford N. Sherman eds., (New York: Family Service Association of America, 1961), pp. 18-19.

5. Jay Haley, ed., Changing Families: A Family Therapy Reader (New York: Grune and Stratton, 1971), p. 6.

6. Sporakowski, "What's it All About? An Overview of Family Therapy," p. 61.

7. Morris B. Parloff, "The Family in Pscyhotherapy," Archives of General Psychiatry, (May, 1961), p. 447.

8. Murray Bowen, "The Use of Family Theory in Clinical Practice," Changing Families: A Family Therapy Reader, Jay Haley ed., (New York: Grune and Stratton, 1971), p. 160.

9. Nathan W. Ackerman, "The Future of Family Psychotherapy," p. 34.

10. Ibid., p. 36 .

11. Nathan W. Ackerman, Treating the Troubled Family (New York: Basic Books, Inc., 1958), p. 87.

12. Don Jackson and Virginia Satir, "Review of Psychiatric Development in Family Diagnosis and Family Therapy," Exploring the Base for Family Therapy, p. 35. 
13. Ackerman, Treating the Troubled Family, p. 54.

14. Parloff, "The Family in Psychotherapy," p. 447.

15. Ibid., p. 448.

16. Ackerman, Treating the Troubled Family, p. 100.

17. Parloff, "The Family in Psychotherapy," p. 448.

13. Ibid., p. 448.

19. Jackson and Satir, "Review of Psychiatric Development in Family Diagnosis and Family Therapy," p. 34.

20. Parloff, "The Family in Psychotherapy," p. 448.

21. Jackson and Satir, "Review of Psychiatric Development in Family Diagnosis and Family Therapy," p. 34.

22. Ibid., p. 40.

23. Sporakowski, "What's it All About? An Overview of Family Therapy," p. 61.

24. David H. 01son, "Marital and Family Therapy: Integrative Review and Critique," Journal of Marriage and the Family (November, 1970), p. 503.

25. Jay Haley, "Family Therapy: A Radical Change," Changing Families: A Family Therapy Reader, Jay Haley, ed. (New York: Grune and Stratton, 1971), p. 277.

26. Fran Page, "Family Contracting," (Mimeographed copy of presentation to Tualatin Valley Guidance Clinic, November, 1976), p. 2.

27. Skynner, Systems of Family and Marital Psychotherapy, p. 383.

28. Ibid., p. 383.

29. Ibid., p. 383.

30. Haley, "Family Therapy: A Radical Change," p. 274.

31. Bernard L. Bloom, Community Mental Health: A Historical and Critical Analysis (Morristown, New Jersey: General Learning Press, 1973), p. 11.

32. Ibid., p. 9.

33. Shirley Cooper, "The Swing to Community Mental Health Movement," Social Casework (September, 1968), p. 277.

34. Ibid., p. 279. 
35. Murray Levine and Adel ine Levine, A Social History of Helping Services: Clinic, Court, School, and Community (New York: Appleton-CenturyCrofts, 1970), p. 11-12.

36. Herbert C. Schulberg, "Future Steps in Implementing Mental Health Plans," Perspectives in Community Mental Health, Arthur J. Bindman and Allen

D. SpiegeT, eds. (Chicago: ATdine Pubtishing Co., 1969), p. 122.

37. Ackerman, "The Future of Family Psychotherapy," p. 5.

38. John F. McDermott and Walter Char, "The Undeclared War Between Child and Family Therapy," p. 427.

39. Ibid., p. 430.

40. 01son, "Marital and Family Therapy: Integrative Review and Critique," p. 503 .

41. Parloff, "The Family in Psychotherapy," p. 449.

42. Skynner, Systems of Family and Marital Psychotherapy, p. 383.

43. 01son, "Marital and Family Therapy: Integrative Review and Critique," p. 504 .

44. Virginia M. Satir, "The Family as a Treatment Unit," Changing Families: A Family Therapy Reader, p. 139.

45. 01son, "Marital and Family Therapy: Integrative Review and Critique," p. 504 .

46. Jay Haley, "Approaches to Family Therapy," Changing Families: A Family Therapy Reader, pp. 228-235.

47. Haley, "Family Therapy: A Radical Change," p. 284.

48. Ibid., p. 284.

49. Bowen, "The Use of Family Theory in Clinical Practice," p. 162.

50. Nathan W. Ackerman, "The Growing edge of Family Therapy," Progress in Group and Family Therapy; C.J. Sager and H.S. Kaplan, eds. (New York: Brunner/Mazel, 1972), p. 441.

Chapter II B.

1. Nina R. Garten and Herbert A. Otto, The Development of Theory and Practice in Social Casework (Springfield, Illinois: Charles C. Thomas, 1964), p. 324. 
2. Ibid., p. 324.

3. Robert W. Roberts and Robert H. Nee, eds. Theories of Social Casework (Chicago: University of Chicago Press, 1970), p. 8.

4. Ibid., p. 14 .

5. Mary Richmond, What is Social Casework? (Russell Sage Foundation, 1922), p. 70.

6. Bertha Reynolds, "Rethinking Social Casework," The Family (Vol. XVI, 1935), p. 235.

7. Regina Flesch, "Treatment Goals and Techniques in Marital Discord," Social Casework (Vol. XXLV, No. 10, 1948), p. 388.

8. Ibid., p. 388.

9. M. Robert Gomberg, "The Specific Nature of Family Case Work," A Functional Approach to Family Case Work, Jessie Taft, ed. (Philadelphia Pennsylvania: University of Pennsylvania Press, 1944), p. 147.

10. Ira D. Glick M.D. and Jay Haley, Family Therapy and Research--An Annotated Bibliography (New York: Grune and Stratton, 1971).

11. Don D. Jackson, "The Question of Family Homeostasis," Psychiatric Quarterly Supplement (Vol. XXXI, No. 1, Part I, 1957), Pp. 79-90.

12. Werner W. Boehm, "The Social Work Curriculum Study and Its Implications for Family Casework," Social Casework (Vol. XL, No. 8, 1959), p. 433.

13. Marie Jahoda, Current Concepts of Positive Mental Health (New York: Basic Books, 1958), p. 53.

14. M. Robert Gomberg, "Family Diagnosis--Trend in Theory and Practice," Social Casework (Vol. XXXIX, No. 2 and 3,1958), p. 73.

15. Nathan W. Ackerman, The Psychodynamics of Family Life (New York: Basic Books, 1958).

16. Alfred A. Messer M.D., The Individual in His Family, An Adaptational Study (Springfield, IlTinois: Charles C. Thomas, 1970), p. 140.

17. Ibid., p. 140.

18. Ibid., p. 140.

19. Donald R. Bardill and Francis J. Ryan, Family Group Casework-- A Casework Approach to Family Therapy (Washington, D.C.: Catholic University of America Press, 1969), p. 64.

20. Ibid., p. 64 . 
21. Frances Scherz, "Family Treatment Concepts," Social Casework (April, 1966), p. 251.

22. Dorothy Fahs Beck and Mary Ann Jones, Progress in Family Problems-A Nationwide Study of Clients and Counselors Views of Family Service Agency Services (New York: Family Service Association of America, 1973), p. 68.

23. Ludwig L. Geismer et.al., Early Supports for Family Life: A Social Work Experiment (Metuchin, New Jersey: Scarecrow Press, 1973), p. 170.

Chapter III

1. J. Tovey and N. Kosterlitz, Beginners and Advanced Family Therapy Workshops (Department of Continuing Education,1976).

2. Casebook in Family Diagnosis and Treatment (New York: Family Service Association of America, 1965), p. 4.

3. Grace Coyle, "The Expanding Theoretical Base of Social Work," (Reprinted from Social Casework New York: Famlly Service Association of America, $1964)$, p. 95.

Chapter V

1. Murray Bowen, "The Use of Family Theory in $\mathrm{Cl}$ inical Practice," Changing Families: A Family Therapy Reader (New York: Grune and Stratton, 1971), p. 186. 


\section{BIBLIOGRAPHY}

Ackerman, Nathan W. The Psychodynamics of Family Life: Diagnosis and Treatment of Family Relationships. New York: Basic Books, Inc., 1958.

Ackerman, Nathan W., Frances L. Beatman and Sanford N. Sherman. Exploring The Base for Family Therapy. New York: Family Service Association of America, 1961.

Ackerman, Nathan W. Treating the Troubled Family. New York: Basic Books, Inc., 1966.

- Family Process. New York: Basic Books, Inc., 1970. Family Therapy in Transition. Boston: Little, Brown and Co.,

Bardill, Donald R., and Frances J. Ryan. Family Group Casework. Washington: The Catholic University of America Press, 1969.

Beal, Edward W. "Current Trends in Training of Family Therapists," American Journal of Psychiatry. (February, 1976), pp. 1-3.

Beck, Dorothy Fahs and Mary Ann Jones. Progress on Family Problems: A Nationwide Study of Clients' and Counselors Views on Family Agency Services. New York: Family Service Association of America, 1973 .

Be11, John Elderkin. Family Therapy. New York: Jason Aronson, 1975.

Bernard, Jessie. The Future of Marriage. New York: World Publ ishers, 1972.

Bloom, Bernard L. Community Mental Health: A Historical and Critical Analysis. Morristown, New Jersey: General Learning Press, 1973.

Boehm, Werner W. "The Social Work Curriculum Study and Its Implications for Family Casework," Social Casework. Vol. XL, No. 8 (1959).

Boszormenyi-Nagy, Ivan and James Framo (eds.). Intensive Family Therapy. New York: Harper \& Row, 1973.

Boszormenyi-Nagy, Ivan and Geraldine M. Spark. Invisible Loyalties. New York: Harper \& Row, 1973.

Camp, Howard. "Structural Family Therapy: An Oatsider's Perspective," Family Process. (October, 1973), pp. 553-584.

Carroll, Edward J. "Family Therapy: Some Observations and Comparisons," Family Process. (March, 1964), pp. 178-185. 
Claghorn, John M. and Sol Levin. "Training Family Therapists by Setting Learning Objectives." American Journal of Orthopsychiatry. (Apri1, 1973). pp. 250-258.

Cooper, Shirley. "The Swing to Community Mental Health Movement," Social Casework. (September, 1968), pp. 275-286.

Family Service Association of America. The Intake Process: Six Papers on Intake Procedures and Short-Term Treatment. Reprinted from Social Casework. New York: Family Service Association of America, 1964.

- The Expanding Theoretical Base of Casework. Reprinted from Social Casework. New York: Family Service Association of America, 1965.

- Casework Treatment of the Family Unit. Reprinted from Social Casework. New York: Family Service Association of America, 1965.

- Casebook on Family Diagnosis and Treatment. Reprinted from Social Casework. New York: Family Service Association of America, 1965.

- Casebook on Family Treatment Involving Adolescents. New York: Family Service Association of America, 1967.

Ferber, Andrew, Marilyn Mendelsohn and Augustus Napier. The Book of Family Therapy. New York: Science House, Inc., 1972.

Fisher, Esther. Divorce: The New Freedom. New York: Harper \& Row, 1974.

Flesch, Regina. "Treatment Goals and Techniques in Marital Discord," Social Casework. Vol. XXLX, No. 10 (1948).

Friedman, Alfred S., John C. Sonne, Jean P. Barr, Ivan Boszormenyi-Nagy, Gertrude Cohen, Ross V. Speck, Jerome E. Jungreis, Geraldine Lincoln, Geraldine Spark, Oscar R. Weiner. Therapy with Families of Sexually Acting-Out Girls. New York: Springer Publishing Co., 1971.

Garten, Nina R. and Herbert A. Otto. The Development of Theory and Practice in Social Casework. Ill inois: Charles C. Thomas, 1964.

Geismer, Ludwig L., (et.al.). Early Supports for Family Life: A Social Work Experiment. New Jersey: Scarecrow Press, 1973.

Glick, Ira D. and Jay Haley. Family Therapy and Research -- An Annotated Bibliography. New York: Grune and Stratton, 1971.

Gomberg, Robert il. "Family Diagnosis--Trend in Theory and Practice," Social Casework. Vol. XXXIX, No. 2 and 3 (1958). 
. "The Specific Nature of Family Casework," A Functional Approach to Family Casework. Pennsylvania: University of Pennsyivania Press, 1944.

Gottesfield, Harry, Chongk Rhea, Glen Parker. "A Study of the Role of Paraprofessionals in Community Mental Health," Community Mental Health Journal. (August, 1970), pp. 285-291.

Group for the Advancement of Psychiatry. The Field of Family Therapy. Report \# 78, 1970.

Haley, Jay and Lynn Hoffman. Techniques of Family Therapy. New York: Basic Books, Inc., 1969.

Haley, Jay (ed.). Changing Families: A Family Therapy. Reader. New York: Grune \& Stratton, 1971.

Howels, J.G. Family Psychiatry. Edinburgh: 01iver \& Boyd, 1963. - Theory and Practice of Family Psychiatry. New York: Brunner/ MazeT, 1971.

Johoda, Marie. Current Concepts of Positive Mental Health. New York: Basic Books, 1958.

Klemer, Richard. Marriage and Family Relationships. New York: Harper \& Row, 1970.

Laycock, A.L. Adolescence and Social Work. London: Routledge \& Kegan Paul, 1970.

Lesoff, Reevah. "Foster's Technique: A Systematic Approach to Family Therapy," Clinical Social Work Journal. (December, 1971), pp. 520-537.

Levine, Murray and Adeline Levine. A Social History of Helping Services: Clinic, Court, School, and Community. New York: Appleton-CenturyCrofts, 1970.

McDermott, John F. and Walter Char. "The Undeclared War Between Child and Family Therapy," Paper presented at the annual meeting of the American Academy of Child Psychiatry, December 1973. (reprint.)

Martin, Freda. Family Therapy for Individual Therapy (And Vice Versa). Typewritten copy of paper presented at the Tavistock Clinic, London, England, January 1975.

Messer, Alfred. The Individual in His Family, An Adaptational Study. Illinois: Charles C. Thomas, 1970.

Minuchin, Salvador. Families and Family Therapy. Cambridge: Harvard University Press, 1974. 
Mottola, W.C. "Family Therapy: A Review," Psychotherapy: Theory, Research and Practice. (Apri1, 1967), pp. 116-124.

Novak, Michael. "The Family Out of Favor," Harper's Magazine. (April, 1976), pp. 37-46.

01 son, David H. "Marital and Family Therapy: Integrative Review and Critique," Journal of Marriage and the Family. (November, 1970), pp. 501-538.

Parl off, Morris B. "The Family in Psychotherapy," Archives of General Psychiatry. (May, 1961), pp. 445-451.

Pollock, Otto. "Issues in Family Diagnosis and Family Therapy," Journal of Marriage and Family. (August, 1964), pp. 279-287.

Reynolds, Bertha. "Rethinking Social Casework," The Family. Vol. XVI (1935).

Reynolds, Mary K. and Joseph T. Crymes. "A Survey of the Use of Family Therapy by Caseworkers," Social Casework. (February, 1970), pp. 76-81.

Richmond, Mary. What is Social Casework?. Russell Sage Foundation, 1922

Roberts, Robert W. and Robert H. Nee (eds.). Theories of Social Casework. Chicago: The University of Chicago Press, 1961.

Sager, Clifford J. and Helen Singer Kaplan, (eds.) Progress in Group and Family Therapy. New York: Brunner/Mazel, 1972.

Satir, Virginia. Conjoint Family Therapy: A Guide to Theory and Technique. Palo Alto, California: Science and Behavior Books Inc., 1964. - People Making. Palo-Alto, California: Science and Behavior Books, Inc., 1972 .

Scherz, Frances. "Family Treatment Concepts," Social Casework. (April, 1966), pp. 221-262.

Schulberg, Herbert C. "Future Steps in Implementing Mental Health Plans," Perspectives in Community Mental Health. Chicago: Aldine Publishing Co., 1969, p. 122 .

Skynner, Robin A.C.. Systems of Family and Marital Psychotherapy: New York: Brunner/Maze1, 1976.

Sporakowski, Michael J. and Paul R. Mills, Jr.. "What's It All About? An Overview of Family Therapy," The Family Coordinator. (January, 1969), pp. 61-68. 
Stamm, Isabel L. "Family Therapy," Casework: A Psychosocial Therapy. New York: Random House, 1972, pp. 203-227.

Strean, Herbert S. The Casework Digest. Metuchan, New Jersey: The Scarecrow Press, 1969.

- The Social Worker as Psychotherapist. Metuchen, New Jersey: The Scarecrow Press, 1974. - (eds.). Social Casework: Theories in Action. Metuchen, New Jersey: The Scarecrow Press, 1971.

Sugar, Max (ed.). The Adolescent in Group and Family Therapy. New York: Brunner/Maze 1, 1975.

Walrond-Skinner, Sue. Family. Therapy. London: Routledge and Kegan Paul, 1976.

Zuk, Gerald and Ivan Boszormenyi-Nagy (eds.). Family Therapy and Disturbed Families. Palo Alto, California: Science and Behavior Books, Inc., 1967. 
APPENDIX A

\section{INTERVIEW SCHEDULE}

Questions regarding agency support of family therapy:

1. Name of agency Type of agency: (Public Private)

2. Fee schedule: None Sliding Scale Set Fee other

3. Does the agency have a waiting list for families? If so, for how long a wait?

4. What are the agency hours?

8:00 or 9:00 a.m. to 5:00 p.m. Mondays through Fridays?

Evenings? How frequently?

Saturdays?

5. Are home visits made? If so, how frequently?

6. Which of the following best describes your assessment of the agency's interest in working with the family unit?
a. slightly interested
b. moderately interested
c. very interested

7. What supervision of training does your agency provide for those working with the family unit?
a. utilization review
b. stipends to attend workshops
c. psychiatrist or other professional on the staff for use as consultants.
d. opportunities for use of video tape as training device
e. other

Questions regarding treatment:

8. Do you consider yourself a family therapist? 
9. There are two approaches therapists use in working with the family unit. One focuses on eliciting expressions of family feeling; the other focusses on restructuring family behavior patterns.

In your opinion, improvement in the functioning of the family unit is most likely to occur through:
a. eliciting expressions of family feeling
b. restructuring family behavior patterns
c. combining both approaches

10. Think of the last five families you have had in treatment. Which of the following treatment modes have you used:
a. none of the time
b. some of the time
c. most of the time
d. all of the time

Individual treatment

Mother and Child (children)

Father and Child (children)

Total family group

11. Do you work with a co-therapist? If yes, how often?
a. none of the time
b. some of the time
c. most of the time
d. all of the time

Questions regarding worker's training:

12. What is your highest degree? When and where did you receive it?

13. Did you have any special training in family therapy while you were in school? If yes, briefly describe it.

workshop:

seminar or other structured training program:

name of trainer:

approximate date of training:

length of time of training: 
14. Have you had any special training in family therapy since you received your degree? If yes, briefly describe it.

workshop:

seminar or other structured training program:

name of trainer:

approximate date of training:

length of time of training:

15. How did the training in family therapy affect your feeling of competency in working with families?

16. Is it your impression that your training influenced you to work more of ten with families than with individuals?

Questions not directly related to hypotheses.

17. What in your training in family therapy do you consider to be of most help in your work with families?

18. What in your training in family therapy do you consider to be of the least help in your work with families?

19. In the last year have you attended any professional meetings in family therapy? If so, please describe.

20. If you could take further training, where would you go for it?

21. Are you familiar with any local training programs. If so, please describe.

Final question regarding hypothesis \#1:

Here is one definition of family therapy. (hand interviewee card with definition.) This definition was developed by the Committee on Family Diagnosis and Treatment established by the Family Service Association of America some years ago. (1961).

22. Is it your impression that your personal style of working with families would accord with this definition.
a. none of the time
b. some of the time
c. most of the time
d. all of the time 
APPENDIX B

AGENCIES USED IN THE STUDY:

1. Mr. Fred Hutchinson, Executive Director

Albertina Kerr Center for Children

2307 N.E. Flanders

Portland, Oregon $97232 \quad 233-5247$

2. Mr. Stuart Stimme1

Boys and Girls Aid Society

2301 N.W. Glisan

Portland, Oregon $07210 \quad 222-9661$

3. Mr. Julian Taplin, Program Director

Carl V. Morrison Center for Youth and Family Servioe

3355 S.E. Powell Blvd.

Portland, Oregon 97202 232-0191

4. Mr. Ocie Trotter, Director

Center for Community Mental Health

6329 N.E. Union

Portland, Oregon 97211 289-1167

5. Diane H. Browning, M.D.

Child Psychiatry Outpatient Clinic

3181 S.W. Sam Jackson Park Rd.

Portland, Oregon $97201 \quad 225-8646$

6. Mr. Richard E. Collins

Children's Psychiatric Day Treatment Center

C.D.R.C. North Unit

P.0. Box 574

Portland, Oregon $97201 \quad 225-8068$

7. Mr. Larry Miller, Regional Manager

Children's Services Division

516 S.E. Morrison

Portland, Oregon 97214 229-6895

8. Mr. Roy Odren, Manager

Children's Services Division

Albina Branch Office

5022 N. Vancouver

Portland, Oregon 97211 280-6993 
9. Mr. Austin Robert, Manager Children's Services Division 4506 S.E. Belmont

Portland, Oregon $97215 \quad 238-8275$

10. Ms. Dolores Morgan, Executive Director Delauney Mental Health Center 6419 N. Portsmouth Blvd.

Portland, Oregon 97203 285-987.1

11. Dr. Buell Goocher, Director

Edgefield Lodge

Route 2, Box 61

Troutdale, Oregon 97060 665-0157

12: Mr. Alvin Rackner, Executive Director Jewish Family and Child Services

1130 S.W. Morrison

Portiand, Oregon $97205 \quad 226-7079$

13. Mr. Robert E. Duea, Executive Director Lutheran Family Services of Oregon

635 N.W. 18th Street

Portland, Oregon 97209 228-7613

14. Mr. Ronald Yoder, Director

Metropolitan Family Service

2281 N.W. Everett

Portland, Oregon $97210 \quad 228-7238$

15. Mr. Harold Ogburn, Director

Multnomah County Juvenile Court

1401 N.E. 68th

Portland, Oregon 97213 248-3468

16. Mr. Ross Miller, Executive Director

Parry Center for Children

3415 S. E. Powell Blvd.

Portland, Oregon 97202 232-0191

17. Mr. James McConnell, Project Director Portland Action Comittees Together 3534 S.E. Main St.

Portland, Oregon 97214 233-8491

18. Ms. Marion Basso, Director

Salvation Army Family Service Division 1200 S.E. 7th

Portland, Oregon 97214 233-6079

19. Sister Mary William, Administrator

Villa St. Rose 597 N. Dekum

Portland, Oregon 97217 283-2205
20. Father Abbot, Executive Director

William Temple House 615 N.W. 20th

Portland, Oregon 97210 226-3021 
APPENDIX C

October 7, 1976

Mr. Richard E. Collins

Children's Psychiatric Day Treatment Center

CDRC -- North Unit P.0. Box 574

Portland, Oregon 97201

Dear Mr. Collins:

We are second year graduate students in the Portland State University School of Social Work. For our practicum requirement, we intend to explore the nature of family counseling and therapy offered by social agencies in Multnomah County. This study necessitates our interviewing professional social workers from a sample of agencies involved in direct service to families .

May we have your approval to interview one of your workers? Our interview will be brief, requires only general information about work with families and will be held at the worker's convenience. We will telephone you sometime the week of October 18 to 22 for your response.

If you have any questions, please call us at one of the numbers listed below. Our practicum advisors are Ms. Marian Ayerza and Ms. Nancy Koroloff. They are available for discussion of the requested interview. Should you wish to contact them, they can be reached at the School of Social Work at 229-4712.

Sincerely,

Ms. Margaret Labby

Ms. Betsy McCartor 